\title{
Political settlements and the delivery of maternal health services in rural Uganda
}

Badru Bukenya ${ }^{1}$

\section{Frederick Golooba-Mutebi ${ }^{2}$}

February 2019

${ }^{1}$ Department of Social Work and Social Administration, Makerere University

Email correspondence: bbukenya@chuss.mak.ac.ug; badrub@gmail.com

2 Independent researcher and Honorary Research Fellow, University of Manchester

Email correspondence: fgmutebi@yahoo.com

ISBN: 978-1-912593-15-6 


\begin{abstract}
Technical questions, such as systems development and management; governance, the role of service users in financing and decision-making and resource availability, have long dominated research on healthcare provision in developing countries. The importance of the broader political context, specifically the way power is organised and exercised and the extent to which it meets the acceptance of a country's ruling elites, or, more specifically, the prevailing political settlement, is usually disregarded (DFID, 2010:22). This ESID-commissioned research explored whether, and the extent to which, 'the balance or distribution of power between contending social groups and classes, on which [the Ugandan] state is based' (di John and Putzel, 2009:4) matters with regard to government capacity for delivering maternal health services. Findings indicate that within Uganda's weak-dominant political settlement, sub-national level settlements exert a profound effect on the capacity and commitment of local government to deliver services. Since the mid-2000s, the health sector in Uganda has been governed for political ends, rather than geared towards higher levels of performance. This has undermined any system-wide efforts to improve service delivery. Case study material from two otherwise very similar districts, Ssembabule and Lyantonde, which record very different levels of progress in reducing maternal mortality, illuminates this argument. At the district level, good performance is driven by developmental coalitions of local politicians, bureaucrats, health sector professionals and civil society organisations with the capacity and commitment to devise and enforce innovative approaches to governing the sector.
\end{abstract}

Keywords: Uganda, maternal health services, politics of health service delivery, maternal health in rural Uganda, political settlements and health delivery in Uganda, political economy of health

Bukenya, B. and Golooba-Mutebi, F. (2019) Political settlements and the delivery of maternal health services in rural Uganda. ESID Working Paper No. 113. Manchester, UK: The University of Manchester. Available at www.effective-states.org

This document is an output from a project funded by UK Aid from the UK government for the benefit of developing countries. However, the views expressed and information contained in it are not necessarily those of, or endorsed by the UK government, which can accept no responsibility for such views or information or for any reliance placed on them. 


\section{Introduction}

Technical questions, such as systems development and management; governance, the role of service users in financing and decision-making, and resource availability, have long dominated research on healthcare provision in poor developing countries. If ever they are asked, questions about the role of politics in service delivery often revolve around whether the management of healthcare systems and facilities is private or public, centralised or decentralised (Turshen, 1999; Foley, 2010; Fassin, 1992; Jaffre and Olivier de Sardan, 2003; Leonard, 2000). The importance of the broader political context, specifically the way power is organised and exercised, and the extent to which it meets the acceptance of a country's significant elites, or, more specifically, the prevailing political settlement, is usually disregarded (DFID, 2010:22). The research reported here explored whether and how much 'the balance or distribution of power between contending social groups and classes, on which any state is based' (di John and Putzel, 2009:4) matters with regard to the capacity of any government for social provisioning. It looks at two rural districts in Uganda.

\subsection{The political context}

While still fighting the then Obote government in the early 1980s, Uganda's ruling party, the National Resistance Movement (NRM), signalled its intention to reconfigure state-society relations once the war ended. The NRM outlined their plans in their 'Ten-point pogramme'. ${ }^{1}$ To some, this document was the basis of a social contract between the NRM and the people of Uganda (Hickey, 2003). Two critical points that are relevant to the current study can be picked from this. The first is what was listed as point number one: democratisation. This started with establishing intimate relationships with local communities in its operational zones. The foundation on which the relationships rested was elected organs called resistance councils. Through them, communities discharged security and administrative functions on the basis of collective action. After the war, the NRM introduced them throughout the country and also used them as the foundation for reforming, through decentralisation, the hitherto centralised local government system. They subsequently played key roles in post-war reconstruction, specifically in service provision (Burkey, 1991; Tidemand, 1995).

Decentralisation began in 1993 and culminated in the devolution of power to local authorities, subsequently accompanied by significant financial resources. It was at a time when the orthodoxy of the Washington Consensus emphasised the importance of liberalising developing-country economies and democratising their politics. Unlike governments that donors had bounced into reforms they found unpalatable, and were therefore reluctant to implement, Uganda was different. The NRM government had independently decided on the broad outlines of the reforms that it wanted to implement, entailing the reconfiguring of politics in general, and dispersing power and responsibility from the centre to local governments. $^{2}$

\footnotetext{
${ }^{1}$ http://www.austria-uganda.at/dokumente/Ten-Point\%20Programme.pdf

${ }^{2}$ Its ambitions were well articulated in its Ten-Point Programme.
} 
There was therefore a coincidence of enthusiasm for decentralisation on the part of both the government and donors. The government sought to achieve several objectives through devolution. Some were intended to secure political goals, while others addressed challenges such as poverty and poor service delivery. The emphasis on poverty and service delivery pointed to the pro-poor orientation of the policy and the government. Through decentralisation the government sought to achieve:

- Equitable distribution of resources among local authorities and, within them, freedom for local managers from centrally imposed constraints, and the development of organisational structures tailored to local circumstances;

- Political and administrative control over services at the point of delivery, a clear link between taxation and service provision and, consequently, improved accountability and effectiveness in actual delivery;

- Popular participation and, through it, beneficiary ownership of locally implemented activities;

- Improved capacity of local authorities to plan, finance and manage the delivery of services and, consequently, public sector performance through enhanced local decision-making and political control (see Uganda Government/Ministry of Local Government (1993)).

Another observation from the Ten-Point Programme relates to the nature of the health system that the NRM promised to build. Point No. 6 committed it to 'restoration and improvement of social services', including healthcare. A closer look at what the leadership had in mind as the means of achieving this objective reveals that it did not promise a sophisticated modern health system of a curative orientation. Rather, it aspired to build one that prioritised preventive action by lay health workers. In order to ensure that 'essential social services are provided for everybody', the NRM asserted: 'the only thing we need to ensure is a large number of medical assistants, health assistants and the availability of medicine'. It was emphatic in declaring that 'the former two should not be a problem [to get], given the large number of school-leavers'. Once recruited by government, they would engage in 'mobilisation of the masses' and in conscientising them 'to know the consequences of the diseases they suffer from, but which are easily curable or preventable'. Curative services would constitute a lower priority. And, in many ways, this was in keeping with the then prevailing orthodoxy within the donor community. The orthodoxy emphasised the importance of primary healthcare services at the expense of tertiary services.

The NRM therefore came to power with clear and specific ideas about what was needed to improve social provisioning, and the role that members of the public would play in the processes envisaged to achieve this objective and wider ambitions.

\subsection{The political settlement and service delivery in Uganda}

After it seized power, the NRM suspended competitive adversarial multi-party politics and established an inclusive government into which they brought members of other political parties as individuals, under a 'no-party' (movement) system (Mugaju, 2000). However, even as they created space for other political actors to play key roles in public life, the NRM 
retained sufficient power and authority to determine the general direction of post-war politics and reconstruction. The suspension of party politics and the inclusion in government of members of potentially rival parties was seen as necessary, given the NRM's inheritance of a sharply divided society because of ethnic, regional and religious sectarianism. Creating long-term political stability was seen as dependent on new rules governing entry into, and the practice of, politics. These rules would require groups and individuals seeking to join the newly formed ruling coalition to abide by certain standards of conduct as the basis for their inclusion.

Under the so-called movement system, no new political parties were to be formed. Those already in existence were confined to their headquarters in Kampala. They were then effectively demobilised by the prohibition against sponsoring candidates for election and recruiting new members. The restrictions allowed the NRM, over a period of 20 years, and despite the exit of members of other parties, to consolidate its hold on power and establish a hegemonic dominance over political space (Rubongoya, 2007; Tripp, 2010). Meanwhile, the suspended parties weakened significantly as their leaders grew old and retired from politics and new ones created factions that tore many apart as they jostled for power and position (Carbone, 2007), especially after multi-party politics was restored.

Besides demobilising political parties, the government enacted legislation to ensure that the potentially 'troublesome' civil society sector was kept in check. In addition to requiring civil society organisations (CSOs) to renew their registration annually, the government spelt out what they could and could not do. Annual registration allows the government to de-register those that might prove troublesome. These measures have ensured that CSOs exercise caution in choosing where to focus their advocacy and influencing activities, being careful not to antagonise the government.

These measures enabled the government to enjoy many years of freedom from electoral pressures and other potentially destabilising contestations. It was not until 2001 that it came under strong pressure, when a faction of the ruling elite whose members had exited from the coalition first attempted to unseat President Museveni (Kobusingye, 2010). Facing a real possibility of losing power for the first time, the government conducted a viciously violent presidential campaign, hitherto the most violent in Uganda's history. Since that time, both the NRM and other political parties have been deploying ever-increasing sums of money to fund their political activities, including electoral campaigns. It has reduced electoral contests to competitive clientelism. Far from being won or lost on the basis of competing visions of how to improve the lot of the ordinary voter, for example, the key decisive consideration has become money, with candidates who offer the largest amounts standing the best chance of winning, whether in national- or local-level elections.

Therefore Uganda's political settlement has evolved from a strongly dominant party/dominant leader type under the 'Movement' (1986 to 2005) to a dominant leader/weak party settlement, a process that started with the re-introduction of multi-party competition in 2005. While the NRM's dominance as a political organisation has somewhat diminished, President Museveni remains an overly dominant personality in this weakly institutionalised organisation. His authority within the NRM and the government is unassailable, although this 
does not always translate into capacity to get his ambitions or wishes implemented, because of weak institutional structures and accountability systems. The NRM's weak institutionalisation is evident in the non-enforcement of internal rules and in ad hoc decisionmaking. Both stem from the party's lack of structures that function as stipulated by its statutes. Influential party insiders and other commentators attribute this state of affairs to the chairman's desire to keep the party weak and therefore under his control and open to manipulation.

Meanwhile, opposition political parties remain too weak to mount an effective challenge, despite benefiting greatly from moral and financial assistance by international actors seeking to promote the cause of multi-party competition. Although they have grown in visibility and popularity and, to some extent, strength, their capacity to influence policy and the general conduct of the government remains limited. The NRM is therefore in no danger of losing elections, not least because of the opposition parties' limited reach, factionalisation, lack of resources and meagre memberships, and the government's disruption of their activities and denial of access to financial resources.

The imperative to keep opposition parties weak and unable to mount an effective challenge for power has assumed greater importance than, say, service delivery, in recent years. A key factor has been mounting pressure from dissenters within the NRM's own ranks, civil society groups and, sometimes, traditional institutions such as monarchies, each making political demands from time to time. These features of the national-level political context have knockon effects on local-level politics within a highly devolved system of local government, and how it impacts such things as service delivery (Golooba-Mutebi, 2005; Green, 2015). They can be taken advantage of, either to good effect or to devastating effect. In these circumstances, the quality and motivations of local leaders and their capacity for collaboration is a significant influence on service delivery (Golooba-Mutebi and Bukenya, 2014).

In theory, the limited space for distractive contestation should have allowed the government to achieve much success in its policy pursuits, provided they were technically sound. There is nothing to suggest that its policies, especially in the health arena on which this research is focused, are not or have not been technically sound. However, the picture that emerges from Lyantonde and Sembabule districts, where ethnographic research (Shaffir and Stebbins, 1991) on which this paper draws was conducted, is one of significant differences in policy outcomes. These differences merit investigation in terms of their drivers. It is possible that the overall political context and the NRM's use of patronage as a tool to manage and maintain the ruling coalition, have shielded the government from having to prove their service delivery credentials for purposes of regime maintenance. This suggests that the defection of dissenters from the NRM and from the broad-based government in the late 1990s, and their metamorphosis into active political competitors and the return to adversarial multi-party politics in 2005 , have had negligible impact, if any, on service delivery. 


\section{Maternal health services in Uganda}

Accounting for over 20 percent of the total disease burden, maternal and child health conditions constitute the highest total burden of disease in Uganda. The persistently poor maternal health outcomes stem from poor quality provision and low utilisation of health services along the care-seeking continuum, from before pregnancy, during pregnancy, childbirth, and to the post-partum period $(\mathrm{MoH}, 2013)$. As per the health sector strategic plan - the roadmap for accelerating reduction in maternal morbidity and mortality - the government undertook to address maternal health concerns through four main interventions:

- Building capacity in emergency obstetric care to address the direct causes of maternal deaths.

- Increasing access to skilled attendance at birth to enable timely detection and management of complications during pregnancy.

- Promoting family planning to enable women to plan their pregnancies and avoid conceiving too early, too late, and too frequently.

- Enhancing antenatal care services to prevent, detect and treat conditions such as malaria, anaemia, HIVIAIDS and others that constitute indirect causes of maternal deaths.

According to Uganda's Ministry of Health, by increasing a woman's awareness of potential complications and danger signs during pregnancy, good prenatal care can prevent up to a quarter of maternal deaths. Successfully implemented, therefore, these four priorities would tackle the main direct and indirect causes of maternal deaths in Uganda: haemorrhage, obstructed/prolonged labour, abortion-induced complications, and postpartum sepsis; ${ }^{3}$ and malaria, anaemia, and HIV and AIDS. ${ }^{4}$

However, after nearly five years of implementing the health sector strategic plan, the successes have been modest. There are many bottlenecks in the system: limited availability of medicines and supplies, poor coordination, poor infrastructure, shortage of financial and human resources, and resistance at household level to recommended practices. The factors account for the low coverage by many priority interventions. Other challenges include logistical problems pertaining to poorly maintained roads, and lack of amenities, especially water and electricity. All this accounts for the stagnation of most maternal health indicators during the last five years. ${ }^{5}$

As with all social services, responsibility for delivering maternal health services was decentralised. The 1995 constitution and the 1997 Local Government Act mandate district local governments to plan, budget and implement health policies and health sector plans (MOH 2010/11-2014/15). Through district service commissions, local governments appoint and deploy health workers in their respective areas. Financing comes from the Central Government Primary Health Care (PHC) grants. Policies are implemented through a tiered health structure comprising health centres II to IV. Health centres II (HCII) are the lowest-

\footnotetext{
${ }^{3}$ These are the direct causes.

${ }^{4}$ Indirect causes.

${ }^{5}$ See Appendix 2.
} 
level units, providing only outpatient services. Where they are unable to deal with a case, they refer patients to higher-level units. HCIII are the second-level units. They can handle delivery and provide laboratory services. HCIV are meant to function as small hospitals, with the necessary equipment for emergency surgical and obstetric care, and for supervision and support for service delivery at lower-level health facilities. District hospitals provide tertiary care. Evidence from the two study districts shows that the severity of constraints to service delivery varies from one district to another and is influenced to a degree by local-level political dynamics and how districts relate to national-level political institutions.

\subsection{Health sector governance arrangements and policy coalitions for maternal health}

Leadership and management within Uganda's health sector started deteriorating in the 1970s after members of the medical fraternity began to flee the country because of political instability and declining quality of governance (Mutibwa, 1992). Under the NRM government, the situation registered some improvement during the second half of the 1990s before it began to deteriorate again in the 2000s. Up to the early 2000s, Uganda's health policy was more coherent, donor fragmentation was minimal, and budgeting was more closely tied to results. This period is also fondly remembered as 'a time when technocrats were able to drive the process' (Croke, 2012) and the Ministry of Health $(\mathrm{MoH})$ enjoyed strong political leadership by the then health minister, Dr Chrispas Kiyonga. However, since 2001 the ministry has not had stable leadership, as it has received fresh ministers every electoral cycle. The high ministerial turnover and the absence of an overarching vision driven by either the presidency or the ruling party have deprived the ministry of much-needed stability and consistency in its operations. And then there is the deleterious effect of national politics on policy-making and staff deployment, which has caused high turnover of senior officials and delays in replacing them (Buse and Booth, 2008). Also significant is the disruption stemming from the appointment and posting of presidential advisors and ruling-party cadres and activists to management positions within $\mathrm{MoH}$ and the sector more generally.

These factors, and the channelling of vast amounts of money into the sector and the $\mathrm{MoH}$ through internationally funded projects (see below), have created several power centres and bred rivalries that have impacted negatively on the esprit de corps that survived the Amin and Obote years. Consequently, the $\mathrm{MoH}$, the natural leader in the sector, is highly factionalised, so much so that some people, although still reporting to their offices regularly, behave as if they are no longer employed there. Others turn up as and when they choose to, and in that way contribute to the absenteeism that afflicts the sector as a whole. Consequently, there is little sense of collective ownership over policies or initiatives. While the scale of these developments overall is difficult to establish, it is clear that they have impacted negatively on the ministry's capacity to fully carry out its designated functions.

Populist instincts and Uganda's increasingly adversarial political contests explain President Museveni's short-term(ist) decisions that impact on the sector in ways that are not amenable to building a strong cadre of leaders or to getting it to address in a consistent way the needs of the ordinary service user. The populist abolition of user fees in 2001, and a salary increase for medical workers in 2004 and 2012, are good examples, as is the posting by State House, without reference to the Health Service Commission, of presidential advisors 
and ruling-party activists to decision-making positions in the health sector. In 2009, in the run-up to the campaigns for the 2011 presidential elections, the president instigated the creation of the Medicines and Health Services Delivery Monitoring Unit (MHSDMU). With a broad mission to 'improve health services in the country', ${ }^{6}$ the unit operates under the auspices of State House, rather than $\mathrm{MoH}$, and is headed by the president's personal doctor.

Political decisions to introduce such initiatives without consulting the leadership in the health sector reflect the relative lack of political influence among officials within the high echelons of the sector and raise questions about the president's trust in the $\mathrm{MoH}$ leadership. The rapid growth in the number of districts (from 34 in 1990 to 112 in 2010), many of which lack the human, financial and infrastructural capacity to operate effectively, is yet another case. One of its consequences is the emergence of weak, poorly led and poorly facilitated local governments whose capacity for delivering services to citizens is severely limited (Cammack et al., 2007). And the larger the number of districts, the further the capacity of the ministry to provide leadership and perform its supervisory functions is undermined (Golooba-Mutebi 2012).

In assessing the effectiveness of service delivery in Uganda, it would be remiss to disregard the influence of foreign actors. The country has received large amounts of foreign assistance in the form of financial resources and expertise, some of it directed at strengthening the health system (see Appendix 3). Interventions by bilateral and multilateral actors have influenced the way the government has approached social provisioning in terms of the strategies it has chosen for addressing general and specific problems. Key respondents within the ministry and the sector at large acknowledge the critical role of donor resources in enhancing the sector's delivery capacity. However, there is a strong view within the same circles that donors wield too much influence on decision-making processes, so much so that it leads to distortion of priorities and, to an extent, further weakening of already weak systems.

While the late 1990s witnessed a reconsideration of the state's role in development and the emergence of the drive for in-country coordination of donor activities, coinciding with the shift in the political settlement, these developments were soon followed by a trend that saw most donors withdraw from SWAPS to off-budget project support. Since the mid-2000s, over 50 percent of development assistance for health has been off budget. Project funding increased dramatically through vertical global health initiatives (GHIs) such as the Global Fund to Fight AIDS, Tuberculosis and Malaria (GFATM), the United States President's Emergency Plan for AIDS Relief (PEPFAR), and the Global Alliance for Vaccines and Immunisation (GAVI), from USD250 million in 2004 to USD500 million in 2006.

These developments are a matter of concern for many within the sector. The influence of GHIs has contributed to dysfunctions in policy-making and implementation and has led to tensions and fights within $\mathrm{MoH}$. This has stemmed partly from a donor proclivity for establishing new, often parallel, decision-making and implementation structures. Structures that are meant to play coordination roles, such as the Health Policy Advisory Committee

\footnotetext{
${ }^{6}$ See, http://hmu.go.ug/index.php/about-us/vision-and-mission (accessed 28 January 2019).
} 
(HPAC) $^{7}$ that sought to promote SWAPs, have been rendered powerless. A key problem is competition and duplication by the more resourced AIDS Partnership Committee supported by PEPFAR and the country coordinating mechanism of the Global Fund. Projects do not channel resources to the priority areas as per the health sector strategic plan. Instead, resources are earmarked for specific diseases like HIVIAIDS and Malaria (Okwero et al., 2015).

At the sub-national level, donor-funded projects have made a tremendous contribution to efforts to improve service delivery, or even to extend it to remote areas that are otherwise under-served. However, the gains have a dark side in some areas. $\mathrm{MoH}$ decries their skewed coverage that leaves some regions, especially Karamoja and Northern Uganda, underserved. Local-level research reveals that, in some districts, work plans are reactive and sometimes made to conform to external, rather than local or national, funding priorities, requirements and programme guidelines (Golooba-Mutebi and Bukenya, 2014). Project financing also betrays donor preference for contracting private firms and NGOs to deliver services rather than using government health facilities. One explanation for this is an unstated view within the government that where donors want to choose their priorities, they should be allowed to do so:

'They bring in money we don't have, but they come with a straitjacket. They do not necessarily give you what you want. You have to keep bargaining. It is your duty to reject aid, but it is a struggle. Their priorities are not our priorities. They like projects where they can post personnel and spend on vehicles. They get their way because the president does not want to confront them. He says it is their money; so let them spend it as they wish. The policy is that it is not your money; so how can you dictate? Let donors come with their intervention and then the government will do what they don't want to do or fund. The president looks at the big picture. He does not want to waste his time with them. He is busy with bigger things where they work well with him. He does not want to compromise that. He works well with them at the strategic level. He does not want to waste time on small things. He is into the strategic, not the tactical. His view is that "let them run around" while he carries on with his programmes. ${ }^{\prime 8}$

This portrayal of donor-government relations gets confirmation from a representative of a key development partner in the health sector:

'We are absolutely part of the problem. The problem is that the needs are vast and every penny counts. So officials are motivated to say "yes" to every initiative. There are lots of personal incentives in this, such as careers to develop. There are many partners, each with their own way of doing things. There is no harmonisation. When you have so many partners who come in

\footnotetext{
${ }^{7}$ HPAC is a forum for the Government, Development Partners and other stakeholders to discuss health policy and to advise on the implementation of the Health Sector Strategic and Investment Plan.

${ }^{8}$ Apparently this is President Museveni's preferred approach to government-donor relations (interview with a former minister of health, 13 April 2015).
} 
with their own priorities, it is difficult to cope. Even governments with greater institutional capacity would not cope. There is a great deal of jumping at every donor that comes in. The government does not provide leadership in managing donor-government relations. The ministry wants to have a very interactive process. The problem is there are simply too many people involved. It is difficult to get through the agenda. There is need for political will on the part of the government to take charge and regulate. ${ }^{9}$

Problems do not stop at the level of interactions between the government and donors. They extend to actual implementation of activities:

'Project implementation overloads officials with work. Each project wants to involve them in its affairs. Every project asks for audience and meetings. The problem is that the ministry is not managing and guiding all the actors. It is not providing leadership overall. People bypass structures and go to the minister. Technical working groups are ignored. The ministry struggles in trying to understand what the different donors have achieved. ${ }^{, 10}$

Amidst all this, although the government has structures that are intended to monitor and coordinate delivery by ministries, agencies and departments, they are constrained and unable to perform their functions as envisaged. There are several reasons for this, including ministries - especially those that are headed by 'powerful' ministers and permanent secretaries - not wanting to be coordinated and refusing to operate transparently in ways that enable officials in charge of monitoring to know what is going on. According to a respondent in one monitoring unit:

'There are ministers who behave like emperors. They are too rigid. The Office of the Prime Minister cannot discipline some ministers. They are too big. The president also takes his time when he is informed, because any action he takes will have political implications. Even some permanent secretaries are too powerful to be disciplined. They have godfathers. If you push a permanent secretary, you may lose your job. You could get messages warning you to be careful. $^{11}$

Equally significant, the NRM as a party does not play direct roles in matters of policymaking or implementation: 'The NRM does not come out to follow up on government programmes. They do not interfere in government programmes. They don't even ask any questions about the implementation of their manifesto. ${ }^{12}$

Within this environment, the health sector in general, and maternal health services in particular, have suffered. For maternal health services, they are a priority in declarations of intent or in as far as the health sector is the subject of pronouncements portraying it as a

\footnotetext{
${ }^{9}$ Interview, 5 May 2015.

${ }^{10}$ Interview with a senior local employee of a donor agency, 7 May 2015.

${ }^{11}$ Interview, 22 April 2015.

12 lbid.
} 
priority for both donors and the government. The government's attitude towards maternal health can be deciphered from resource allocation. While maternal health conditions in Uganda account for over 20 percent of the total disease burden, it attracts only USD50 cents per capita, far below the WHO-recommended USD1.40. Also significant is the weakness of the coalition of maternal health advocates that comprises the $\mathrm{MoH}, \mathrm{CSO}$ and members of parliament, especially women MPs. The latter include influential personalities, among whom is First Lady Janet Museveni, who is also the patron of the Campaign for Safe Motherhood, and the speaker of parliament. Through various committees and for a, such as the Parliamentary Health Committee and the Network for African Women Ministers and Parliamentarians (NAWMP-Uganda), parliamentarians have pushed for relevant policies and programmes for maternal health and secure intermittent government commitment to staffing and funding. For example, parliament convinced the government to contract a loan from the World Bank to procure reproductive health commodities in 2011 and in the same year obtained its consent to lift the ban on recruitment of health personnel (Loewenson and Apunyo, 2011).

Advocacy CSOs have attempted to use litigation to attract the government's attention to the plight of women (Golooba-Mutebi, 2011a). In 2013, over 30 Ugandan CSOs, frustrated by what they perceived as the government's unresponsiveness to the needs of the people, petitioned the Supreme Court to declare that the high rate of maternal deaths in the country was a breach of basic rights. The petition argued that Uganda was not spending the money it promised on maternal health, yet an estimated 16 women were dying daily. The WHO mother and baby package, which the government had agreed to implement, specifies spending of USD1.40 per capita, but, as stated earlier, Uganda spent 50 cents. The groups hoped that an authoritative pronouncement would have shamed the government into taking positive action. Nevertheless they lost the petition and the status quo continued, amidst attempts by individual victims to effect change by seeking legal redress (Golooba-Mutebi, 2011b).

The heath sector actors and their relationships explained here are summarised in Figure 1. The concern of the remainder of this paper is to analyse the implications of all this for the delivery of maternal health services in two rural districts, Lyantonde and Sembabule. 
Figure 1: Health sector settlement

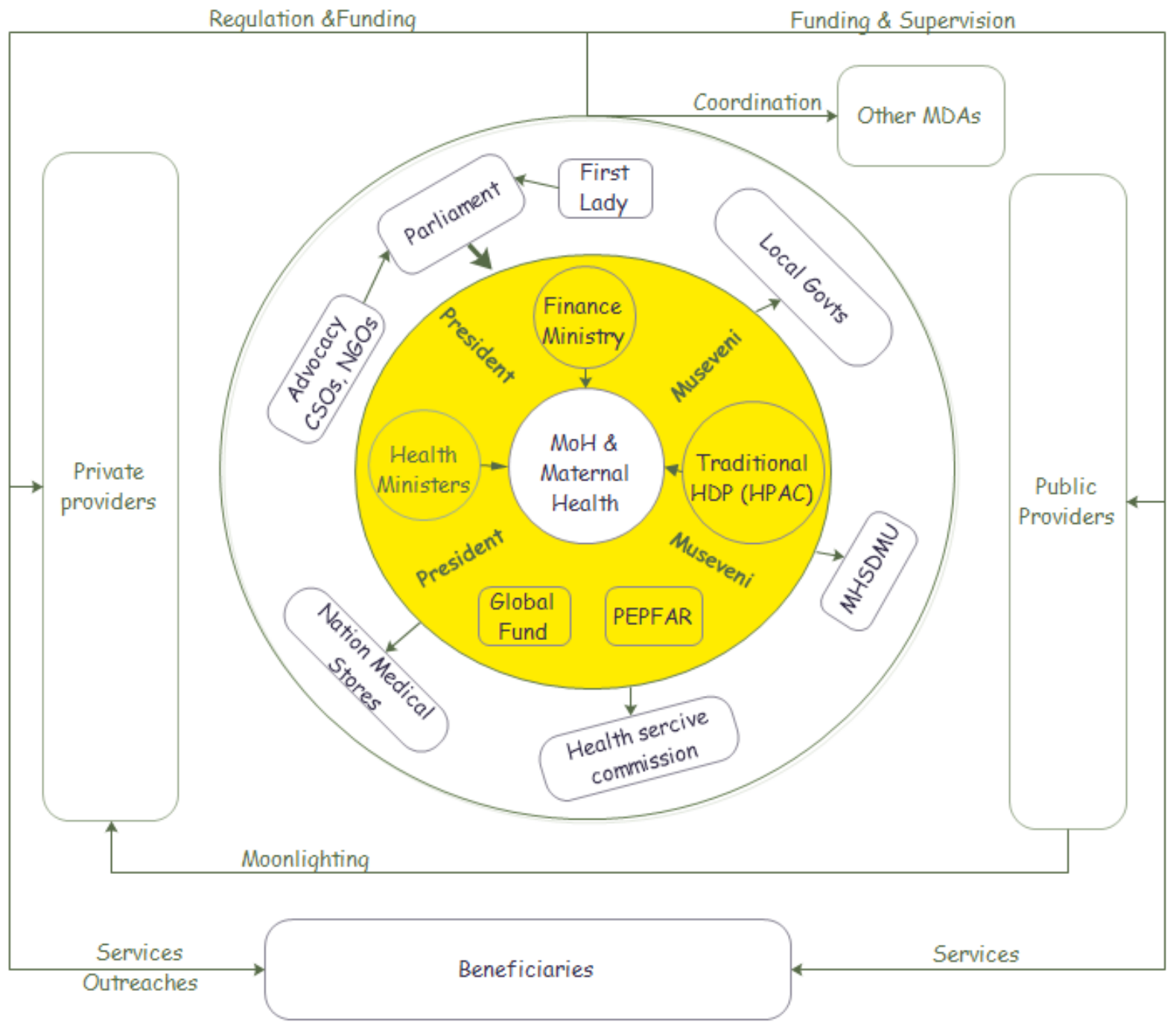

Source: Authors.

\subsection{Case study selection and methodology}

In terms of methodology, this is a comparative case study that largely drew on qualitative methods of data collection. The study employed elite interviews, key informant interviews and focus group discussions (FGDs). The limited quantitative findings used were obtained from review of secondary data.

The study areas were selected on the basis of secondary information from the annual health sector performance reports (district league tables). Between 2007 and 2014, Sembabule consistently featured in the bottom 15, while Lyantonde was always in the top 15 (Figure 2). Lyantonde and Ssembabule districts were also suitable cases for comparison as they are neighbours and share similar socio-cultural and economic contexts (see below and map, Appendix 1).

Fieldwork for this study was done in two phases. The first phase entailed a mapping of the national-level political settlement, and the drawing of its connections with the broad features 
Figure 2: Sembabule and Lyantonde on the MoH district league table $\mathrm{e}^{13}$

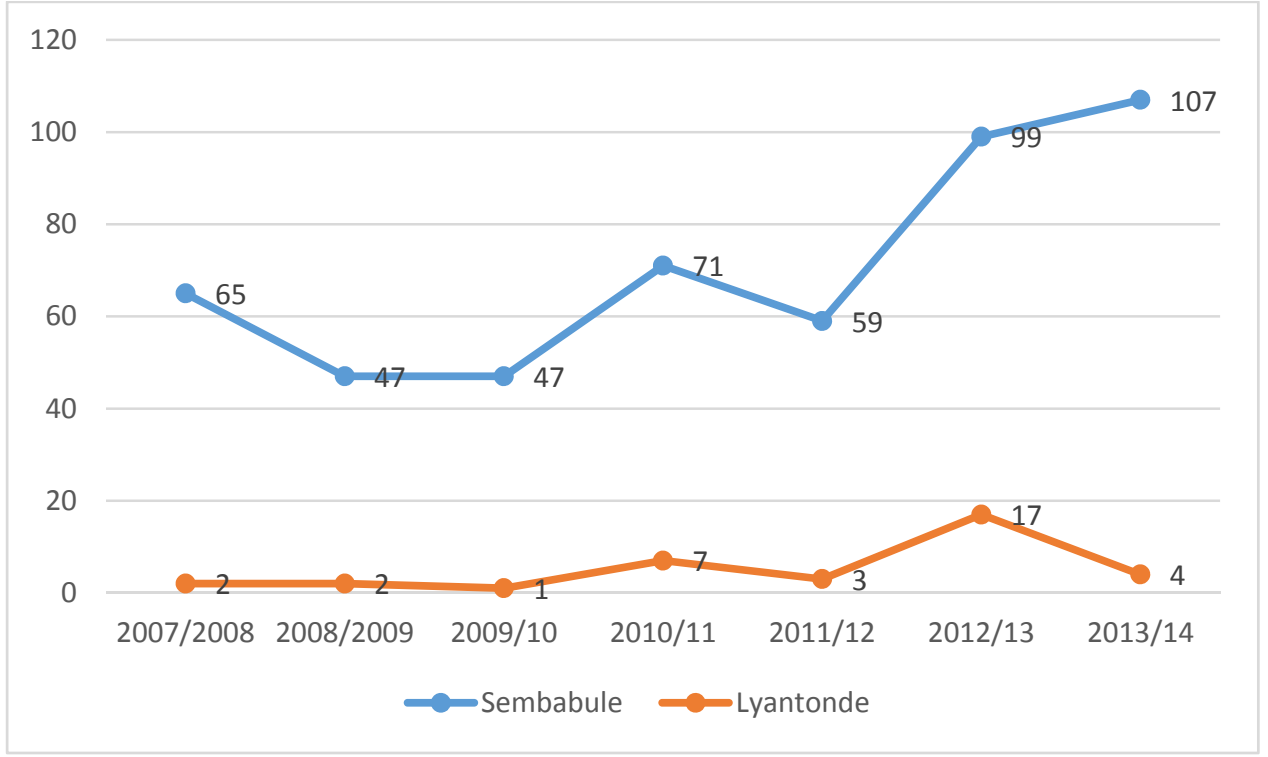

Source: Annual Health Sector Performance reports for various years.

of Uganda's health system and development experience. It identified the key actors within the maternal health domain and investigated the main issues that influence its functioning. It examined institutional capacities and the constraints that key institutions face in trying to deliver on their mandates. We identified the key actors at the national level from line ministries, especially the Ministry of Health and other government agencies, such as National Medical Stores, National Drug Authority, the Medicines and Health Services Delivery Monitoring Unit, members of parliament and donor representatives. We also engaged representatives of CSOs. The subnational level is where maternal health services are delivered and are supposed to be used. Therefore, the second phase entailed data collection from Sembabule and Lyantonde districts. We examined the ways in which district and local government officials and health facilities react to stimuli from high up, how reforms or instructions translate into action and, where there is a disconnect between the national and the local, how officials and health unit administrators manage. Fieldwork was conducted between April and June 2015 using qualitative approaches that prioritised key informant interviews with politicians and technical staff at the district and, to a lesser extent, representatives of CSOs. Health personnel and service users from the main health facility of each district and two lower-level facilities were also interviewed. Overall we conducted 36 elite interviews at the national level and from each of the studied districts, 20 key informant interviews and one FGD with service users from every health facility visited.

The two neighbouring districts (see Appendix 1) are the products of the sub-division of districts into ever-smaller entities. The sub-division of districts accelerated in recent years and became controversial because of its seeming link to President Museveni's mobilisation of political support for his re-election bid (Green, 2010). Sembabule, 168km outside Kampala, is an offshoot of Masaka district, and is only 7 percent urbanised. It has a population of 252,994, of which 127599 are women (Uganda Census, 2014). At 31.7

${ }^{13}$ Between 2007/08 and 2009/2010, Uganda had 80 districts. A lower score reflects better performance. 
percent, poverty levels in the district are higher than the national average of 19.7 percent (see Table 1). Lyantonde, $190 \mathrm{~km}$ from Kampala, is an offshoot of Rakai district. It is also predominantly rural, with a population of 94,573 , of which 47,870 are women. Compared to the national average, poverty is relatively higher, at 26.5 percent.

Table 1: Summary of other vital statistics

\begin{tabular}{|l|l|l|l|}
\hline & National & $\begin{array}{l}\text { Lyantonde } \\
\text { district }\end{array}$ & $\begin{array}{l}\text { Sembabule } \\
\text { district }\end{array}$ \\
\hline Area in $\mathrm{km}^{2}$ & & 864.6 & $2,319.2$ \\
\hline Population (2014) & $34,856,813$ & 94,573 & 252,994 \\
\hline Population density & & 109.4 & 109.1 \\
\hline Population growth rate & 2.88 & 1.8 & 1.9 \\
\hline Doctor-patient ratio posts filled & $1: 24,725$ & - & $1: 69,448$ \\
\hline $\begin{array}{l}\text { \% medical p8 } \\
(2014)\end{array}$ & 57 & 59 \\
\hline Poverty headcount & 19.7 & 26.5 & 31.7 \\
\hline Adult literacy & 71 & 66.9 & 70.4 \\
\hline Life expectancy & 54.5 & 45.5 & 45.5 \\
\hline
\end{tabular}

Sources: UBOS (2014) and NDP II (2015).

\section{Maternal health services in Sembabule}

Of the district's 25 health facilities, four are private. Two-thirds of the public facilities and three-quarters of the private ones are in one of the district's two counties, Mawogola. This seems to be linked the bigger population, the larger number of administrative units, and because the local parliamentarian is one of Uganda's wealthiest and most influential politicians, compared to the less wealthy and less influential MP for Lwemiyaga County, with whom they are arch-rivals.

\subsection{Service delivery by public facilities}

As seen in Table 2, there are two public health centre IV units in the district. The Mawogolabased facility acts as the district hospital. Both have well equipped but non-functional operating theatres. Therefore neither carries out caesarean sections, a key component of emergency obstetric care. One reason for this is the absence of critical personnel, such as anaesthetists. Relatedly, no public facility offers blood transfusion services. Life-threatening conditions requiring blood transfusion are consequently not treatable at government facilities in the district.

There are also problems with the state of the available infrastructure. The in-patient department at Sembabule HCIV, the largest public health facility in the district, for example, was in a dilapidated state at the time of fieldwork. It forced users not to seek services there. Its surroundings also left a lot to be desired. The grass around the buildings was so 
Table 2: Health facilities

\begin{tabular}{|l|l|l|l|l|l|}
\hline Health facility & \multicolumn{2}{l|}{ Lwemiyaga County } & \multicolumn{2}{l|}{ Mawogola County } & Sub-total \\
\hline & Private & Public & Private & Public & \\
\hline Hospital & 0 & 0 & 1 & 0 & 1 \\
\hline Health centre IV & 0 & 1 & 0 & 1 & 2 \\
\hline Health centre III & 1 & 1 & 2 & 3 & 7 \\
\hline Health centre II & 0 & 5 & 0 & 10 & 15 \\
\hline Total & $\mathbf{1}$ & $\mathbf{7}$ & $\mathbf{3}$ & $\mathbf{1 4}$ & $\mathbf{2 5}$ \\
\hline
\end{tabular}

Source: Authors' compilation.

overgrown, it had become a habitat for snakes. One had bitten a health worker only a few days prior to the fieldwork. The facility had support staff and cleaners on the payroll. However, the head (In-charge) was unable to oblige them to do their work, because they lacked basic tools, such as brooms and grass-cutting implements.

'The cleaners use bare hands and grass to clean the toilet! The In-charge is too embarrassed to ask them to do more. His predecessor received money to buy a motorised grass cutter, but he bought a used one. It broke down after only three months. The hospital administration does not want to waste resources on repairing it. When $\mathrm{PHC}$ funds come, priorities like immunisation come first. ${ }^{, 14}$

During fieldwork, the hospital was in total darkness at night, as it had been disconnected from the national electricity grid because of non-payment of bills. The district's main health centre fitted the description 'death-traps', as used by a journalist for health facilities in the district (Mambule, 2014). Potential users preferred to seek services elsewhere, because of its poor state, fearing they might pick up new infections there. ${ }^{15}$ One health worker intimated that smaller private clinics had more in-patients than the government $\mathrm{HC} \mathrm{IV}$, where no single patient was admitted during the team's five-day visit.

These challenges are not unique to Sembabule district. Only 45 percent of HCIV facilities countrywide could do caesarean sections and only 36 percent could do blood transfusions during FY 2013/14 (MoH, 2014). In theory, facilities lacking capacity can refer complicated pregnancies to higher-level facilities, even in neighbouring districts. $\mathrm{MoH}$ expects all HCIV facilities and general hospitals to have functioning ambulances to facilitate referral. Sembabule, however, lacked a functioning referral system.

Their ambulances had been grounded for years. Service users had to improvise and pay for private transportation. However the poor could not afford the cost of public transport,whereby an expectant woman and one caretaker needed approximately USD15

\footnotetext{
14 Health worker, 21 April 2015.

15 Health worker, 21 April 2015.
} 
(UGX 45,000) for a return journey to Masaka Regional Referral Hospital in neighbouring Masaka district. Where referrals occur at night, which is not uncommon for pregnant women, the cost would triple. At Sembabule HCIV, on average 12 pregnant women per week were referred. Poor women, when they are referred to distant facilities, opt for the services of traditional birth attendants (TBAs) ${ }^{16}$ or seek the help of relatives with childbearing experience (Sabiti and Ssebunya, 2012).

Such decisions carry serious implications for the women involved. There is no guarantee that they will not experience life-threatening complications. Hygiene standards are likely to be low, thereby increasing the risk of harmful complications and infections. In the mid-2000s the government of Uganda banned TBAs as part of the wider tide of opinion within the developing world, against service providers without formal training. However, in Sembabule, as elsewhere in Uganda, TBAs fill gaps in the defective formal health system that less than 20 percent of expectant women use to deliver their children (see Table 3). The maternal mortality ratio (MMR) in Uganda would be lower if more expectant women delivered at health facilities.

Table 3: Health indicators in Sembabule district

\begin{tabular}{|l|l|l|l|l|}
\hline Health component & $\mathbf{2 0 1 0 / 1 1}$ & $\mathbf{2 0 1 1 / 1 2}$ & $\mathbf{2 0 1 2 / 1 3}$ & $\mathbf{2 0 1 3 / 1 4}$ \\
\hline Facility deliveries \% & 14 & 55.2 & 17.5 & 11.7 \\
\hline ANC4 \% & 27 & 24 & 25.8 & 19.4 \\
\hline Staffing \% & 44 & 43.1 & 52 & 57 \\
\hline Medicine orders \% & 0 & 25 & 25 & 100 \\
\hline Position in league table & 71 & 59 & 99 & 107 \\
\hline
\end{tabular}

Source: Annual Health Sector Performance reports for various years.

Indeed, maternal death rates as registered at public and private health facilities are low, standing at 168 per 100,000 in 2012/13 and 146 per 100,000 in 2013/14. Meanwhile MMR increases to 438 per 100,000 when deliveries in the community are included ( $\mathrm{MoH} 2014){ }^{17}$ Back in Sembabule, health workers at a public HCIV revealed that a TBA in the neighbourhood delivered between 50 to 80 women a month, far more cases than the facility handled. ${ }^{18}$ Expectant women praised TBAs for their helpful and convenient services and willingness to work in challenging circumstances. ${ }^{19}$ When women went into labour at night, they opted for TBAs rather than public facilities where health workers were unlikely to attend to them, as they worked only during the daytime. Although several service users indicated that the quality of service is much better in private facilities, the costs were prohibitive for the majority.

\footnotetext{
${ }^{16}$ TBAs are 'older women without formal training in midwifery but with skills and experience in preparing and delivering mothers which was passed on to them by their mothers, aunts and other relatives through assimilation' (Sabiti and Ssebunya, 2012).

${ }^{17}$ MMR is a high impact indicator that is obtained through national demographic and health surveys. According to $\mathrm{MoH}$ officials, it is currently not computed for districts.

18 Interview, 21 April 2015.

${ }^{19}$ FGD at Lyantonde HC IV.
} 
Given this reality, some NGOs have ignored the TBA ban and chosen to continue working with them to enhance their midwifery skills. They equip them with the necessary knowledge and skills to help eliminate mother-to-child HIV transmission (EMTCT). TheNGOs teach TBAs to identify complications and encourage them to refer expectant women to health facilities when they see signs of risk. It is significant that officials responsible for enforcing the ban do not enforce it because they too recognise the value and influence of TBAs in the community. However, the services of TBAs have continued to be problematic, especially because it takes a long time for women with complications to seek the services of trained health personnel, often leading to otherwise avoidable deaths. It is estimated that in Uganda about 9 percent of maternal deaths arise from delay in accessing professional care (CDC, 2014). Also, deaths that occur under the watch of TBAs are neither reported nor recorded in the official statistics. This background explains why maternal health indicators in Sembabule are poor in relation to other districts (Table 3).

\section{Service delivery in Lyantonde district}

Unlike Sembabule, Lyantonde has relatively well developed and maintained health infrastructure. For example, many government health facilities have staff living quarters and use solar energy to power equipment, and the district has two functioning ambulances to facilitate referrals. One HCIV facility has been upgraded to hospital status.

At the district hospital, maternity and women's wards were clean and well organised. However, the sector is not without problems. The unit in charge of maternal and child care services, was highly challenged by high patient numbers vis-à-vis the limited number of staff. Of the five medical officers allocated to the department, only two were available for work, while the rest were on study leave. Nonetheless, members of staff were generally committed to their duties. As a team, they set the unit's targets and constantly asked the district biostatistician for data from the District Health Information System (DHIS II). According to one respondent:

'we discuss the health indicators from the DHIS II. On antenatal visits, our performance by March [2015] was 61 percent. I know this is above the national average, but for us we can't celebrate that we are doing very well, because our target was 90 percent. We make action plans to help us follow up. ${ }^{20}$

The use of data in this case contrasts with Sembabule, where data managers revealed that they rarely get requests for data from health personnel. A key factor here is support from the political leadership. In addition to mobilising communities, political leaders have provided a bridge between the health facility and service users. Support included holding to account health workers who might be identified by service users as engaging in misconduct.

And where other problems, such as inadequate hygiene, were identified, there were clear efforts to rectify the situation. At some point, political leaders had been aggressive about

${ }^{20}$ Interview, 1 June 2015. 
tackling problems such as absenteeism, illegal fee charging, and rudeness towards service users. In some cases, the culprits would be arrested and prosecuted. However, the approach had impacted negatively on morale, leading to resignations, with health workers decrying political interference in their work. At the time of the fieldwork, the two sides had taken to collectively searching for solutions to whatever challenges emerged. For example, political leaders also participated in drawing up work plans for the health facilities. Once every month they worked alongside health workers. In that way, they gained insights into their working conditions, roles and expectations. At the district hospital, the resident district commissioner $^{21}$ and the district council chairman (LCV) interacted with health workers once a month during their continuous medical education (CME) sessions.

Although in some hospital departments the quality of service delivery leaves a lot to be desired, both technical personnel and political leaders were aware of the problems and agreed on dialogue being the best course of action. Perhaps as a result, there was evidence of a functional supervision, monitoring and evaluation system. The district has a fairly effective monitoring and evaluation (M\&E) department for health that keeps tabs on the performance of every health unit. In consultation with the district health office (DHO), it distributes performance targets to each unit. In return, units submit progress reports on their respective targets, which are reviewed periodically. According to a key informant in the M\&E department:

'We are strict on quarterly meetings with the facility heads. We invite them to the district. The DHO chairs these meetings. We discuss issues like data management. We share the performance in aggregate form and as disaggregated facility data. For low performers, we try to understand their challenges. Some may lack key personnel, such as midwives. In that case, the district organises to send someone there. Some have one member of staff. When he or she is on leave, the unit closes. So we have to draw action points. ${ }^{22}$

Therefore, despite having lower staffing levels compared to Sembabule, Lyantonde has better maternal health indicators (see Table 4).

Table 4: Maternal health outputs in Lyantonde district

\begin{tabular}{|l|l|l|l|l|}
\hline Health component & $2010 / 11$ & $2011 / 12$ & $2012 / 13$ & $2013 / 14$ \\
\hline Facility deliveries \% & 71 & 73.9 & 59.9 & 74.1 \\
\hline ANC4 \% & 88 & 114 & 47.4 & 61.5 \\
\hline Staffing \% & 38 & 46.2 & 49 & 59 \\
\hline Medicine orders submitted \% & 67 & 66.7 & 67 & 100 \\
\hline Position in league table & 7 & 3 & 17 & 4 \\
\hline
\end{tabular}

Source: $\mathrm{MoH}$ health performance reports for various years.

\footnotetext{
${ }^{21}$ RDCs, who are usually ruling-party cadres or previous supporters of opposition parties who have been induced to defect, represent the president in districts and act as his eyes and ears.

22 Interview, 1 June 2015.
} 


\section{Explaining the dysfunctions in Sembabule: politics and service delivery}

Lwemiyaga and Mawogola counties have two directly elected members of parliament each, a woman and a man. The current male MPs, Theodore Ssekikubo of Lwemiyaga County and Sam Kutesa of Mawogola, are bitter rivals. The rivalry stems from Ssekikubo's victory in the 2001 parliamentary race, over Kutesa's cousin, Sam Rwakoojo. Kutesa is rumoured to be one of Uganda's richest men. He had previously sponsored and got Sam Rwakoojo elected after introducing him to the electorate in 1996. In 2001, Kutesa again invested much time and financial resources in Rwakojo's re-election bid. Rwakoojo's defeat by Ssekikubo ignited one of the fiercest political rivalries in Uganda, with far-reaching consequences:

'There is widespread division, intrigue, and political rivalry in Sembabule, perhaps more than in any other district. Disagreeing NRM factions trade insults, and there are times when they even fire guns. They wear differently labelled T-shirts although they are all yellow. They hold separate rallies.' (Ssali, 2010).

The ensuing polarisation has seen Ssekikubo and Kutesa sponsor rival candidates for elective political offices, including against one another. Such is their dominance that local politicians identify themselves according to their respective camps, each of which recognises and pays allegiance to President Museveni as NRM leader. During the 2006 elections, Ssekikubo's camp triumphed when its candidate for the district council chairmanship defeated his rival from Kutesa's camp. However, during the 2011 polls, candidates sponsored and supported by the Kutesa faction won most leadership positions in the district, especially in Kutesa's own Mawogola County.

After years of intense contestation, during the 2011 elections the Kutesa camp was boosted by Ssekikubo's decision to join a group of youthful NRM legislators in their public criticism of President Museveni and the NRM for diverting from the original ideals of the party, while lamenting the deteriorating state of public services and lack of accountability. In April 2013, the 'rebels' were all expelled from the NRM on account of breaching Rule 4 of the NRM constitution. Rule 4 prohibits the formation of factions. The courts eventually blocked the expulsion while Ssekikubo decided to return to the NRM, thus preserving the great Sembabule rivalry.

At the root of Sembabule's plight are the strong connections between the two dominant local political actors and the all-powerful NRM chairman. Ssekikubo, the MP of Lwemiyaga County is the son of a close Museveni ally and collaborator during the 1980s guerrilla war that brought him and the NRM to power. Also, on account of his father's relationship with Museveni, Ssekikubo lived and worked in State House, the president's official residence, for some years. On the other hand, Kutesa married a cousin to Museveni's wife and then his daughter married Museveni's son. Kutesa's influence is evident in his 2001 re-appointment to the cabinet after parliament censured him in 1999 for corruption and influence peddling. 
Figure 3: Map of Sembabule district showing counties and dominant political factions (2011)

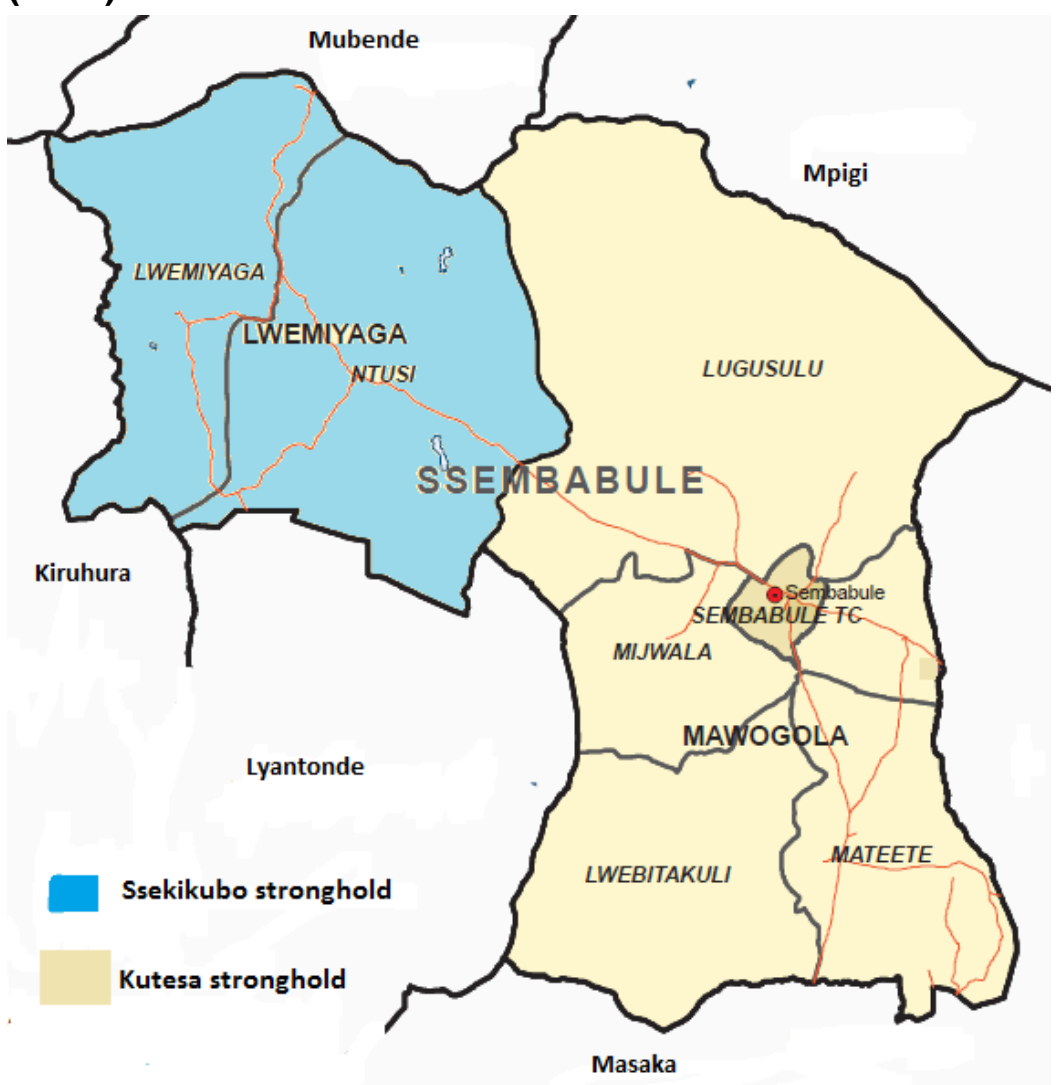

These ties matter when it comes to disagreements among powerful party functionaries. Museveni would not want to be seen to take sides. It matters even more when the feuding parties both enjoy much popular support and are deemed to be important for Museveni's and the NRM's capacity to mobilise electoral support. Alienating one side could mean opening the way for the increasingly aggressive opposition to make inroads into a sizeable constituency. Tolerance for misconduct and indiscipline within the party seems to be an accepted price for keeping opposition parties out of important constituencies. As reflected in Figure 3, Museveni has chosen to play a neutral card in Sembabule, making several attempts to reconcile Kutesa and Ssekikubo and so far failing (Kaaya, 2009; Independent Team, 2010). ${ }^{23}$ Dysfunction in party organs, including those that are responsible for discipline, leaves no clear avenues beyond the party chairman, for reconciling the two rivals.

\subsection{The rivalry's impact on service delivery}

This long-running feud has hampered progress in the district and inflicted damage on service delivery. During the 2006 local elections, for example, the Kutesa camp emerged with 10 out of the 17 district councillors. The outcome created a stalemate at the district headquarters, because the district chairman, Herman Ssentongo, a Ssekikubo ally, refused to constitute the 10-member district executive committee, to avoid including Kutesa's supporters. Without an executive committee, passing the annual district budgets became a challenge for the

${ }^{23}$ See for example: Kaaya (2009); Independent Team (2010). 
entire period that Ssentongo was chairman. Consequently, programmes could not be implemented. An attempt by the minister of local government to resolve the budget impasse failed. The standoff in the council also prevented the establishment of the District Service Commission, as councillors failed to agree on possible membership.

It meant that, between 2006 and 2010, the district could not recruit, confirm, promote, discipline, or retire staff. In 2011, a newly recruited chief administrative officer (CAO) summed up the situation:

'Many key positions in the departments of health, education, works and administration are being manned by staff in acting capacity and some of them lack administrative and other skills for their jobs... this has affected the implementation of government programmes and accountability for government funds' (Aliga, 2011).

The feud has sucked in the civil service. Even district personnel belong to either camp, as most of them are local people and likely to support Kutesa or Ssekikubo, depending on who they are and which county they are from (see Figure 3). The standoff has bred indiscipline within the public service, as political godfathers shield individuals from being held to account. Supervisors will not reprimand their juniors, for fear they will run to the politicians to seek help. As a result, district employees have created new norms that are contrary to those prescribed by the civil service standing orders. A case in point: they work for three days a week, not the official five days. ${ }^{24}$ Apparently within the health sector service, users 'know that on Monday you are most likely not going to find anyone at the health facility. This means they have to suspend their need for medical attention to Tuesday'. ${ }^{25}$

A good example of the link between indiscipline among public servants and politics is one $\mathrm{Dr}$ Kazungu (not real name), whom the DHO and CAO were finding difficult to discipline. He was initially recruited to work as facility head (In-charge) in Sembabule HCIV. The facility being near the district headquarters and therefore serving as the de facto government hospital in the district, his supervisors kept a keen eye on it. However, they soon discovered that he was never at his duty station. The DHO complained to the CAO, who, in turn, after several warnings, submitted his name to the district service commission (DSC) for dismissal because of absenteeism and indiscipline. The DSC did not act as requested, because the doctor had close links to the sitting LCV chairman. Instead of sacking him, the DSC recommended that, as punishment, he be transferred to another health unit, Ntuusi HCIV, which is located a considerable distance away from the district headquarters. ${ }^{26}$

However, the doctor remained defiant and continued to absent himself from duty, apparently because he combined government work with private practice at Bamu hospital, which was

\footnotetext{
${ }^{24}$ The working week in this district starts on Tuesday and their last working day is Friday. We were informed that the district is a 'hard-to-live-in' place, where most workers reside outside it, with many having their homes in Kampala.

${ }^{25}$ Interview, HCIV.

${ }^{26}$ Some respondents felt that his transfer to a distant place was meant to remove him from a station where everybody notices whenever he has not reported for work.
} 
owned by the LCV chairman (Ssekweyama, 2012). According to reports, other government health workers, including the LCV chairman, were working several days a week at Bamu hospital while retaining their full-time positions at government facilities. The case illustrates the breakdown in vertical accountability in the district as the agents engage in misconduct alongside their principals.

With the fusion of politics and public service, well-meaning technocrats lost trust in the formal accountability mechanisms. What they do now is to bypass them with short-term and at times high-handed methods, such as suspending from the payroll personnel who do not report regularly for work. They can do this for several months, or use the police to arrest staff accused of wrongdoing. In 2012, the assistant chief administrative officer (ACAO), with the assistance of the police, ordered the arrest of health workers at Sembabule HCIV on account of their negligent handling of a pregnant woman, who delivered by herself outside the facility. ${ }^{27}$ Following the arrests, there was some improvement at the health facility. However, because leaders did not follow up, things returned to the original state.

The tables were, however, soon turned on the official who had ordered the arrest, when health workers accused him of harassing staff who had been on night duty and were therefore not required to be at work during the daytime. They claimed that those who had been arrested were the most active, while their non-active colleagues were in Kampala and other towns, going about their private engagements. The LCV chairman condemned his action and wanted him punished. He was summoned to a special council sitting to defend himself. However, in the ensuing debate, many councillors suggested that he deserved to be rewarded instead. They argued that he had at least done something that political leaders were scared of doing. When the matter was put to a vote, the result was $17 / 2$ in favour of the officer.

District-based technocrats appointed by the central government have found it difficult to establish careers in Sembabule. In particular, the top offices in administration and health, the $\mathrm{CAO}$ and $\mathrm{DHO}$, have been the most affected, as office holders rarely complete a year in office. At the time of fieldwork, Sembabule had had three CAOs in three years. Moreover, even the fourth CAO in office during fieldwork was already contemplating leaving.

The CAO is an important actor in the operations of a district. S(he) oversees the recruitment, promotion, staff development and, ultimately, service delivery. For example, following failure to attract anaesthetists to Sembabule, the DHT decided that the district should resort to skilling existing staff through in-service training. It was suggested that midwives and theatre assistants be identified for experiential attachment to Masaka regional referral hospital. However, this plan stalled because there was no substantive CAO to sanction it. Similarly, at the time of fieldwork, the district had no substantive DHO. The one in office was working in an acting capacity, the substantive one having left because of tensions with politicians. ${ }^{28}$

\footnotetext{
27 Interview with a district official, April 2015.

${ }^{28}$ Interview with senior male politician, April 2015.
} 
The political squabbles have at times engulfed the office of the resident district commissioner (RDC), ${ }^{29}$ with the previous RDC clashing with Ssekikubo, who accused him of supporting Kutesa. Meanwhile, relations between the current RDC and the LCV chairman are tense over the latter's alleged dereliction of duty. So bad is the relationship that at some point meetings called by the chairman would not be attended by the RDC and vice versa. There was, however, some criticism of the RDC by local actors for not mobilising communities and other stakeholders to improve service delivery in the district.

Nonetheless, a pro-development alliance between the RDC, the CAO and the DHO was beginning to emerge in Sembabule (see Figure 4). However, it was still too weak to turn things around in favour of service delivery. The trio were able to do only small things, such as intimidating errant health workers with threats of removal from the payroll if they did not change their behaviour. Also, by themselves they could influence neither resource allocation for which the district council had responsibility, nor recruitment of staff, which was the responsibility of the district service commission (DSC) operating under the spell of the LCV chairman.

Meanwhile, the citizens were feeling disillusioned about prospects for improvement. For the most part, they castigated Kutesa for neglecting them and focusing disproportionately on politics and seeking to destroy his political opponents: 'The problem that we have with Kutesa is that as soon as we elect him, he leaves for Kampala and doesn't return. The few times he comes here he meets only selected people at his home to talk about party politics'. ${ }^{30}$ However, other service users decried their own failure as citizens to use the power of their votes to dislodge 'unproductive' politicians: 'I think we as voters love money a lot. Those who "box" ${ }^{31}$ us are the ones we vote for, yet leaders elected through such corrupt ways cannot deliver good services'. ${ }^{32}$

The Ministry of Health provides for structures such as health unit management committees (HUMCs) to oversee the functioning of health units and promote participation by service users in decision-making and the management of service delivery. In the early days of decentralisation, they generally worked reasonably well (Golooba-Mutebi, 1999). Over time, however, they have ceased to be active, or they have atrophied out of existence in most places, leaving health facilities entirely in the hands of health workers, with serious implications for local supervision and oversight. In places where they still exist, they 'consist of members who mobilised support for the (LCV) chairperson' when he was campaigning to be elected, and not necessarily of people who are competent. The interactions between health facilities and management committees were visibly weak. Moreover, HUMCs met only when they knew that money for their sitting allowances was available, and the facility In-

\footnotetext{
${ }^{29} \mathrm{RDC}$ is a political appointee representing the Office of the President in the district.

30 Female KI Mateete, April 2015.

31 'Boxing' is a slang that members of the public have coined for giving a bribe. It alludes to the manner in which the giver of the bribe uses a clenched fist to hide and pass on money to the taker.

${ }^{32}$ FGD participant, Sembabule HC IV.
} 
Figure 4: The health sector political settlement in Sembabule

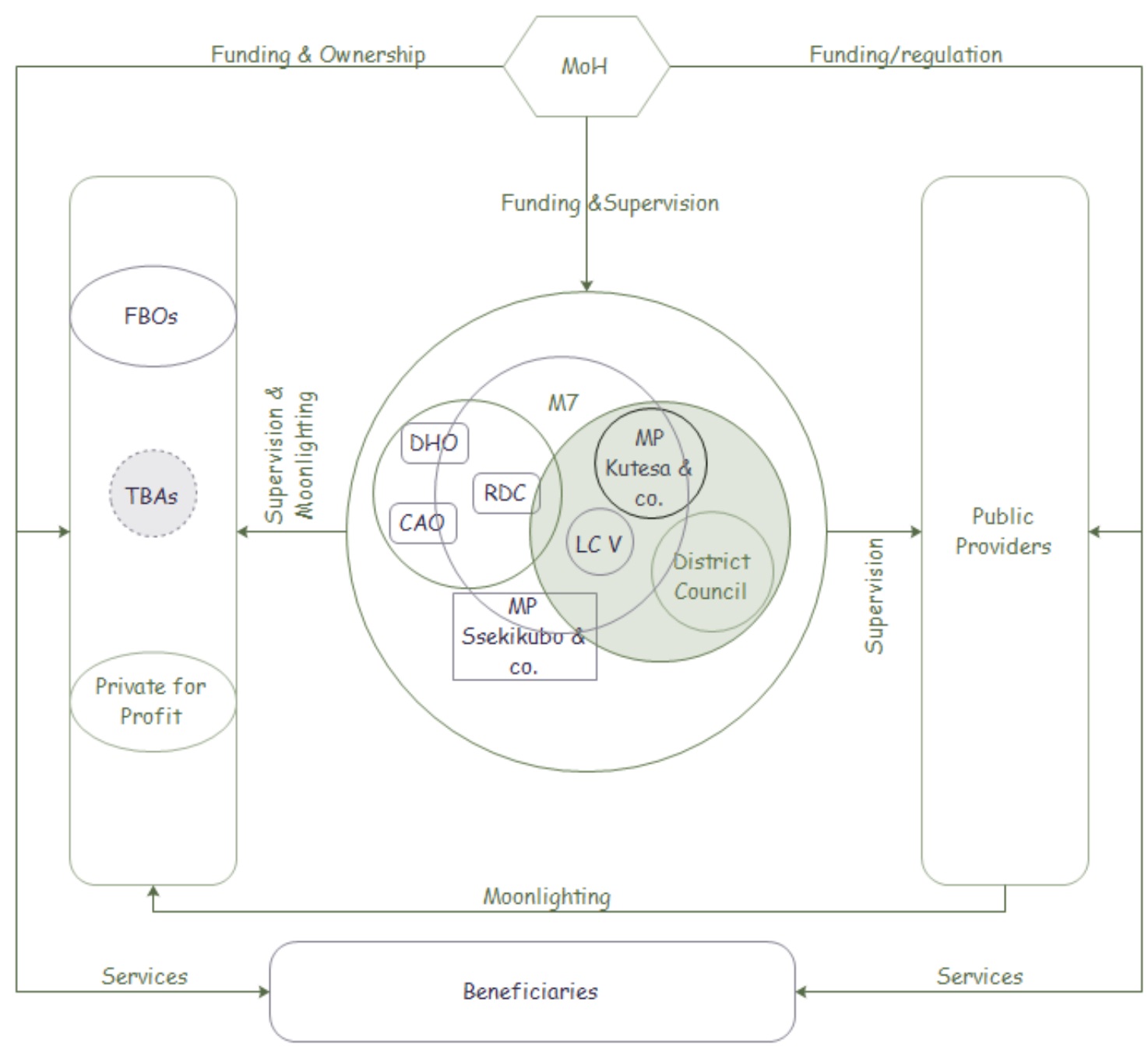

Source: Authors.

charge, whom they were supposed to hold accountable, agreed to the sitting. Generally, HUMCs in the district do not operate as expected. First, they have no clear terms of reference, budgets or work plans. And then bottom-up accountability arrangements are further derailed by feelings of powerlessness within communities, as alluded to by an informant with reference to maternal health:

'It is difficult for ordinary citizens to do anything about maternal health; we cannot hold the providers accountable and our MPs are not helping us. I am personally unable to reach the MPs to talk about the poor health conditions because they are never here. They keep on referring us to the groups they advised us to establish. But you find that improvement of health services is not a priority for most group members.'

Apparently there are more men than women on these committees, although they do not pay much attention to health issues that affect women. Male dominance is linked to sociocultural 
factors; in a community where male domination is taken for granted, men lead in households as well as throughout the communities at large.

Also, Sembabule's peculiar political context, and its impact on the way the health sector works, has been a disincentive for NGOs to seek to implement activities there. Of great significance is the district's reputation for service delivery failures. For NGOs that seek to work in contexts that are conducive to success, Sembabule is one place to avoid.

Politics has affected service delivery negatively in other significant ways. For example, investment in infrastructure such as roads and schools is also the focus of political manoeuvring. Politicians have sought to ensure that their constituencies benefit, regardless of level of need. Moreover, tenders to deliver infrastructure projects are usually awarded politically, to companies from which politicians expect and receive kickbacks. This has had implications for the quality of the work. For example, the roads built through these contracts are of such bad quality that pregnant women worried about travelling on them while in labour due to the risk it entailed to their wellbeing and that of their unborn children. Also, corruption was reportedly rife in personnel recruitment. Some claimed the DSC comprised the LCV chairman's trusted friends, and that they had been instructed to offer jobs only to candidates who paid most money. If true, such practices compromise competence.

\section{Why Lyantonde works}

Unlike Sembabule, Lyantonde has a pro-service delivery political settlement. The political commitment is generalised to all social services, including water and education, with maternal health benefiting through a positive trickledown effect. The key actors in this proservice delivery movement, as reflected in Figure 5, are the district chairman (LCV), the district council, and the proactive resident district commissioner (RDC). Spurred by the meagre resources the district receives from the central government, ${ }^{33}$ the chairman and the RDC have mobilised financial and moral support from strategically positioned politicians, bureaucrats in government ministries, departments, and agencies (MDAs) and members of the business community. The district chairman explained: 'As chairperson you need networks to be effective. You have to identify the right people who can help you mobilise resources. You need to develop good relationships with them. Personal relationships matter

a lot. ${ }^{34}$ The two area MPs are also a positive force in the district. The woman MP donated one of the two ambulances, while her male counterpart, courtesy of his position as minister of state for health, influenced the upgrading of the health centre IV.

The pro-service delivery coalition also includes technical personnel. Efforts have been made to cultivate a harmonious relationship between the two sides. Within the district council, the chairman doubles as the Health Secretary, the position he previously held before he was

\footnotetext{
${ }^{33}$ A CSO KI informed us that the leadership is aware that service delivery in the district cannot solely rely on central government allocations.

${ }^{34}$ Interview, 2 June 2015.
} 
Figure 5: Political settlement in Lyantonde district

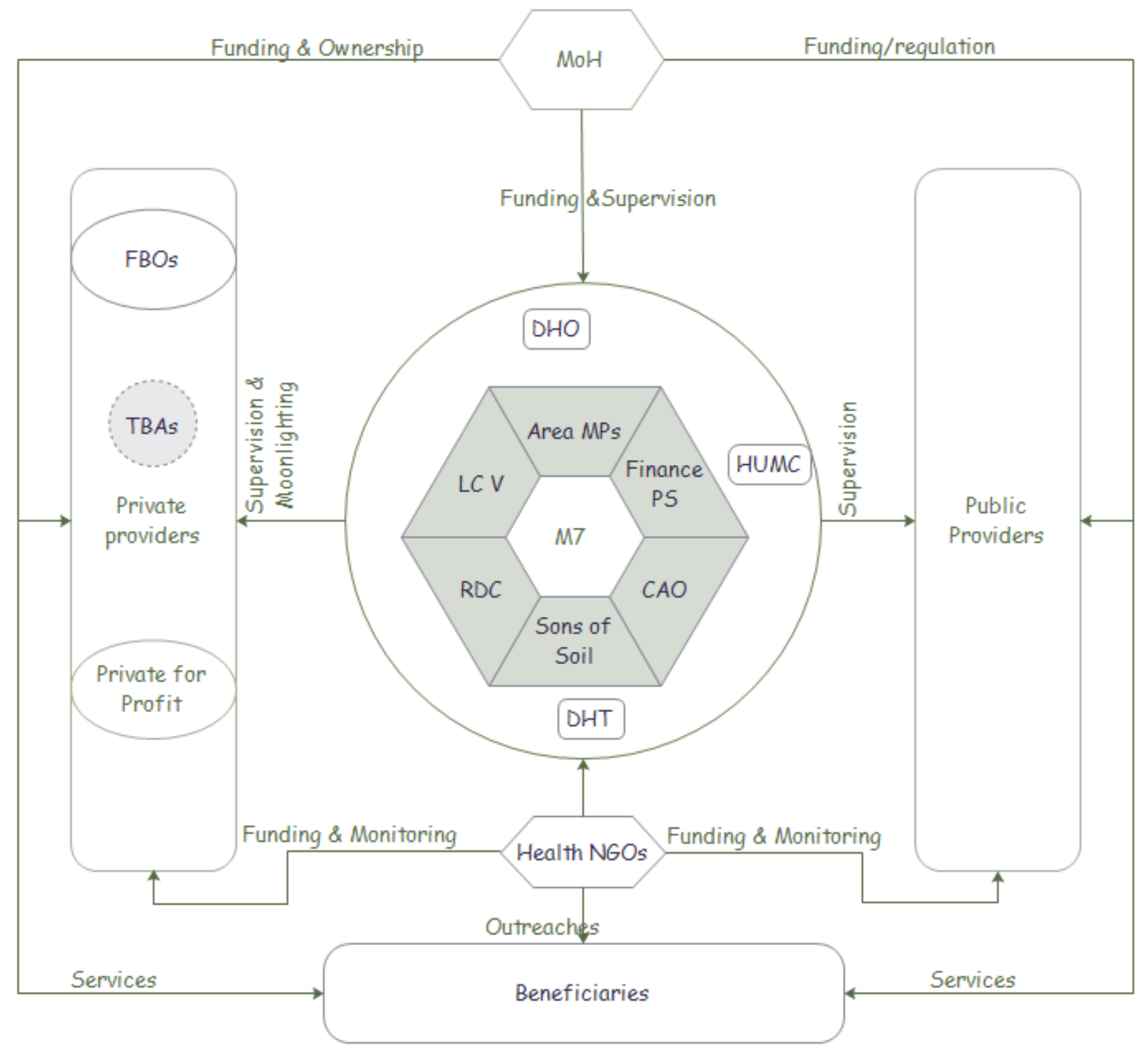

Source: Authors.

elected in 2011. Holding onto the docket has helped him cultivate a good working relationship between political leaders and health workers:

'Before Lyantonde became a district, I was the secretary for health. I supported the DHO in allocating resources for health. We used to supervise together. We worked together with other health workers. We have always worked together as a team. This is why we have managed to keep this good record.'

Personnel at lower health centres lauded the district leadership for being responsive to their concerns. According to an informant at a health facility:

'the chairperson is very helpful. It was through his initiative that bat infestation was eliminated recently. He came the next day after we contacted him. I had 
no light in the delivery ward. When he discovered it, he sent someone to rectify the problem. The problem was with the solar panel. ${ }^{, 35}$

The relationship between technical personnel and elected leaders is strongly symbiotic: 'we the health workers deliver the services and they take the credit. In return they help us to mobilise communities and get the materials and equipment we need to deliver'. ${ }^{36}$ The technical people acknowledge the political leaders' comparative advantage in community and resource mobilisation: 'We used to lobby as technical people, but we would fail. So we sought the support of the politicians. We now engage them systematically'. ${ }^{37}$

Also, the LCV chairman and RDC supervise health programmes at the different public facilities and in the community. Visitors' books and minutes of meetings at the three health facilities where fieldwork was done confirmed that the two officials were in close contact. They are strict on performance targets, as evidenced in $\mathrm{MoH}$ annual performance reports. Whereas no action is taken when $\mathrm{MoH}$ rankings reveal Sembabule's poor performance, in Lyantonde ranking outside the first 10 positions attracts keen attention from the leadership. In 2013 when the district slid more than 10 positions, from fourth a year before, to 17th the leadership asked the DHO to explain. He revealed what happened:

'When we were ranked 17th, I had a hard time. I was bashed throughout that year... I was made to write reports to explain why we performed poorly and what we needed to do to improve. We drew up action plans to help us improve. I felt relieved when we improved in $2014 . .$. '

When the DHO came under pressure, he too cascaded it downwards onto his technical team. The pressure explains why the $\mathrm{DHO}$, whose position is managerial and does not require him to do clinical work, gets involved.

The commitment to service delivery since Kabula became Lyantonde district, has links to feelings of marginalisation that the new local political elite trace to the colonial period, when Kabula was a county within Buganda Kingdom and then, after independence, part of Masaka district, and later of Rakai district. The outsider status felt by some of the county's inhabitants stems from the area having been annexed to Buganda Kingdom from its Ankole counterpart by the British colonialists, and possibly the fact that most belong to language groups that are different from the Baganda, who became their overlords. Perceptions of marginalisation continued after independence, up to the decentralisation reforms of the 1990s, when Kabula became a county of Rakai district. Under Rakai, when the county was approximately $65 \mathrm{~km}$ from the district headquarters, to which it was connected by a road that was often impassable, particularly during the rainy season, service delivery left a lot to be desired (Lyantonde DDP, 2011). The intensity of these feelings is evident in the somewhat exaggerated claims by a district health official: 'most of the health facilities were the other side of Rakai district. The few we had had no equipment.' The claims find amplification in

\footnotetext{
${ }^{35}$ Interview, 3 June 2015.

${ }^{36}$ Interview, 1 June 2015.

37 Ibid.
} 
Lyantonde's district development plan: 'The County lacked most of the basic needs for the welfare of humans and animals, such as water, grass, good soils, rainfall and other resources' (Lyantonde DDP, 2011: 36). ${ }^{38}$

Feelings of marginalisation are therefore a key driver of the determination by Lyantonde's new local political elite to change the area's fortunes. In 2006, when the county was granted district status, the politicians preferred to name the new district after the chief town, Lyantonde, as opposed to inheriting the county's original name, with its association with 'scarcity'. In its short history of existence, the politicians have mobilised to make this symbolic gesture a reality. They possess a keen sense of ownership over the district's evolution and concern about its plight, especially in the health and education domains. The technical personnel have also bought into the political vision.

The district's first DHO, for example, played active roles in community mobilisation, traversing communities and asking residents to contribute money to enable the district administration to rent private properties to house health centres ( $\mathrm{HCll}$ ) to which his office would provide medical supplies and personnel. Through such efforts, the district has increased the number of public health facilities from nine in 2006 to over 20 in 2015. Official records show that 54 percent of $\mathrm{HCll}$ are in rented premises. These efforts have laid a strong foundation for community participation in health-related initiatives (see Box 1).

In their drive to develop the district, its leadership decided to leverage its location for resource mobilisation. It is bisected by the highway that links Uganda to Rwanda, Burundi and the Democratic Republic of Congo, and Lyantonde town to major urban centres, such as Mbarara and Kabale to the south west of the country (see Figure 6). The highway carries a large volume of traffic, which necessitates easily accessible high quality health services:

'I have travelled many times with the RDC and the DHO to the Ministry of Health to meet the permanent secretary, the minister and his minister of state.

I have convinced them of the need to strengthen the capacity of our health sector because we are located on this highway. ${ }^{39}$

The main argument underlying this leveraging of the district's location is that developing its capacity to provide emergency care for travellers is essential, given motor accidents associated with heavy traffic. The argument is strengthened by the absence of welldeveloped health services in neighbouring districts, while the nearest referral hospitals are

\footnotetext{
${ }^{38}$ It is important to contextualise these claims. First, Rakai district, which local elites accuse of marginalising Kabula county, is part of Buganda's Buddu and Kooki counties, which were also annexed by Buganda in the late 19th century, on the eve of colonialism (see, for example, Twaddle, 1993). Moreover, Sembabule, which performs worse than Lyantonde, was also annexed by Buganda from Ankole (Karugire, 1971) and occupies the same physically marginal place as Lyantonde. Second, during the late 1990s, Kabula county as part of Rakai district suffered the same poor delivery of services as other areas (see Golooba-Mutebi, 1999). Nonetheless, that perceptions of marginalisation may not be backed up by facts does not detract from the fact that they are a key driver of commitment to service delivery and socio-economic progress by the new local elite.

${ }^{39}$ Interview with district official, 2 June 2015.
} 
Figure 6: Lyantonde district

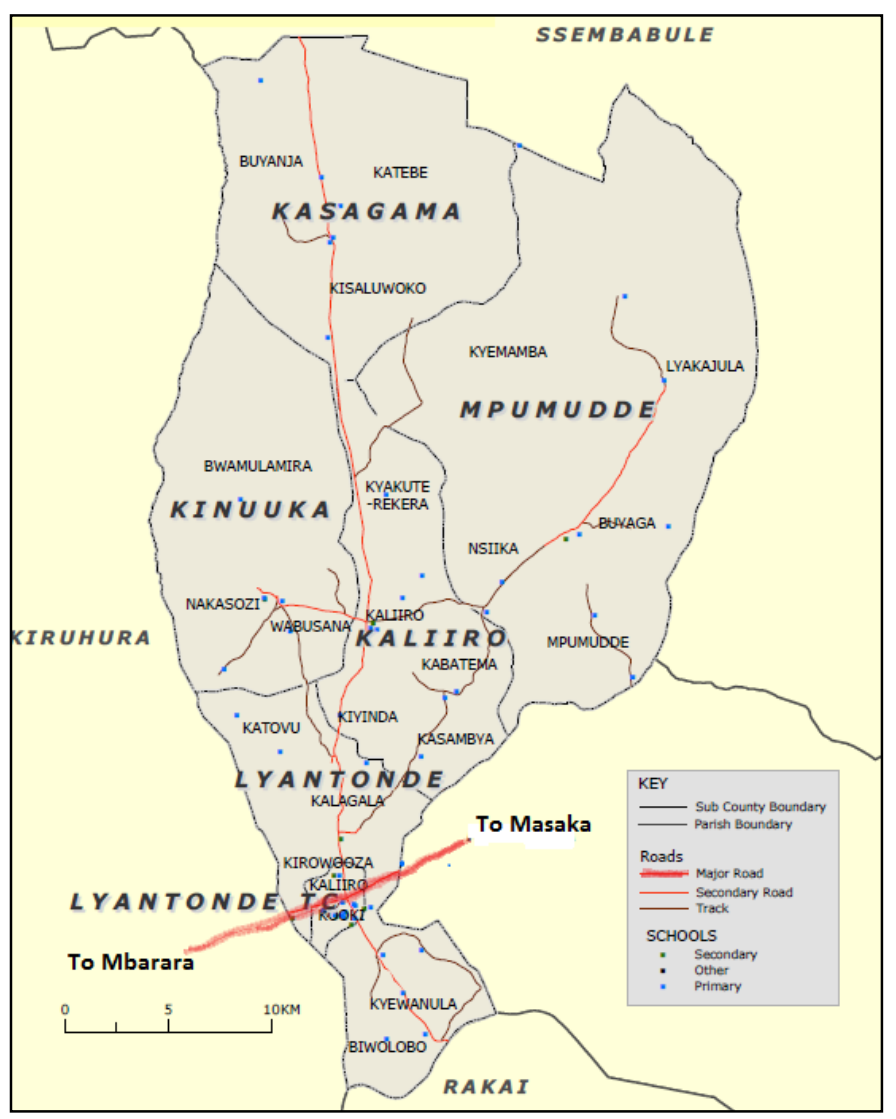

both over $70 \mathrm{~km}$ away. Using the location argument, the politicians persuaded the Ministry of Health to renovate its health facilities, upgrade Lyantonde HCIV to hospital status, ${ }^{40}$ and supply the district with an ambulance.

These developments would not have been possible without the blessing of the Ministry of Finance, Planning and Economic Development (MoFPED), which had to release the required financial resources. The district leadership have commended the MoFPED permanent secretary, who is also a 'son of the soil', for his assistance, as 'All the money that comes here is in one way or another linked to him'. There was some speculation that more money was in the pipeline, with claims that the government had committed to contribute 700 million shillings for the hospital's refurbishment.

\footnotetext{
${ }^{40}$ Some respondents believe, however, that 'son of the soil', the former minister of state for primary health care, helped to upgrade the HC IV to a district hospital status.
} 
Box 1: Community self-help initiative in Kabatema Parish ${ }^{41}$

In 2006, the DHO, Dr Katumba Ssentongo, traversed communities to assess their needs. The district was new, with few health facilities. He mobilised communities to organise and rent space to house parish-level health centres ( $\mathrm{HCll}$ ) to enable the government to give them health workers and essential drugs. The parish initially received drugs from the district, but is currently supplied directly by the National Medical Stores. Kabatema parish has 29 villages. The community agreed to rent a small house in the trading centre. High demand for services and good performance spurred a good Samaritan, Kampala-based but locally born businessman, Mr Kavuya, to construct a bigger building on land donated by the district administration. The new building has piped water and is powered using solar energy.

Although it is a lower-level unit, maternity services have been made available because of the high demand. Limited space, however, renders service provision difficult. A solution has been found in erecting an additional building for outpatient services. The health unit management committee decided that each household makes a one-off donation of UGX 2,000 , using members of village health teams (VHT) to collect it, after elected leaders failed to do so for fear of arousing hostility from potential voters. During fieldwork they had collected UGX 800,000 and bought 10,000 bricks. A member of the community had pledged to donate roofing materials. To ensure compliance with the fundraising, patients seeking services had to produce evidence of contribution before being attended to.

Both the district administration's political and technical wings are supporting this initiative. The district administration is working on the building plan, including its approval. The district chairman is pressuring the district service commission to recruit more personnel for the unit, which he has praised as one of the model health units in the district. The DHO visits and carries out spot checks, even on Saturdays. It means the unit has to remain open on weekends to handle emergencies.

Alongside mobilising technical staff and 'sons of the soil', the leadership has successfully courted NGOs and CSOs to provide support. This is in stark contrast with Sembabule, where officials neglected mobilising and managing non-government players. Many of the NGOs and CSOs in Lyantonde specialise in interventions targeting maternal health. A key informant identified over 10 CSOs working on maternal health in the district. Local but powerful CSOs based in the district included: Salama Shield, Rural Action Community Based Organization (RACOBAO), Child Aid Uganda, as well as faith-based health facilities. National and international NGOs were Mildmay, Save the Children, Uganda Cares, Rakai Health Sciences Project, Action Group for Health Human Rights and HIVIAIDS (AGHA), Reach u Project, Uganda Health Marketing Group (UHMG), Marie Stopes, Pace, Forum for Women in Democracy, and Uganda National Health Consumers Organisation (UNHCO). UNICEF was also active in the district. Some of these actors train midwives and contribute to strengthening general health systems through investment in infrastructure such as clinics, as well as recruitment and wage payment for certain categories of health workers. They also support the district's quarterly monitoring and data collection and participate in review

\footnotetext{
${ }^{41}$ Information for this case study was obtained through interviews health officials and and patients (3 June 2015).
} 
processes that entail midwives from lower-level health centres coming together to review progress and share experiences. Others help with capacity-building for service users and communities to demand for better services. This is done in the form of communitygovernment dialogues in which citizens interface with the heads of various district departments. Although CSOs are important actors in Lyantonde, their influence over the political leadership is limited because of inadequacies in coordinating themselves. Nonetheless, district authorities have accorded them membership of various service delivery committees and they are expected to buy into the district plan. ${ }^{42}$

As part of efforts to enhance the capacity of communities to demand accountability, toll-free telephone numbers have been made available, to enable those who wish to complain or report incidents to do so. Other channels for voicing concerns include village accountability committees. As a result, service users have been emboldened to speak up whenever need arises. A quick internet search of Lyantonde district picks up reports of citizens complaining about poor services. It is now possible for users to ask why they do not get certain medicines and to complain about poor service. Where health workers persist in their bad behaviour, communities can petition for their transfer.

Members of local communities are also known to use 'rude' methods to ensure accountability (see Hossain, 2010). There are reports of angry patients' relatives assaulting health workers. In 2014 the district health office closed Lweshama HCII in Kinuka subcounty for some months after local people attacked its health workers. Complaints by the community about the facility caused the Medicines and Health Services Delivery Monitoring Unit (MHSDMU) ${ }^{43}$ to visit the district at least three times (MHSDMU, 2014). MHSDMU visits usually result in corrective measures being taken. On one such visit, for example, they:

'...tried to arrest one particular medical officer. They organised a meeting at which they had him attend to meet the community, who complained about him. He accepted his mistakes and apologised. So they forgave him following a verbal warning. ${ }^{, 4}$

These developments have concentrated the minds of health workers and bred feelings of insecurity: 'This community is rough. I fear them because I am not a native of this place'. ${ }^{45}$ According to another informant: 'At times they want to beat us up. They want us to do what they demand rather than use our professional judgement'. Such was the situation that officials were talking of sensitising communities about criminal liability for those who might assault errant health workers.

\section{Discussion and conclusions}

These case studies confirm the assertion that politics has a lot of influence on service delivery. Also, they demonstrate that in Uganda local politics matters as much as national

\footnotetext{
${ }^{42}$ Interview, head of programmes of an indiginous NGO, Lyantonde, 1 June 2015.

${ }^{43}$ Unit set up by the president in 2009 , and reporting directly to him, to stop pilferage of medicines and general mismanagement of the health sector.

${ }^{44}$ Interview with male KI, 1 June 2015.

${ }^{45}$ Female health worker.
} 
politics and that, even within the context of a dominant leader/dominant party political settlement at the national level, within decentralised political dispensations, there can be ample space for creativity leading to effectiveness in delivery, or dysfunction leading to disruption. Whether or not politics at the local level becomes a facilitator or blocker depends on its organisation and practice, regardless of the dynamics at the national level, whose contact with and oversight over the local is light-touch. For the purposes of our analysis, politics in Sembabule is such that two strong political factions, into which technical personnel have also been recruited, focus and dissipate most of their energies on fighting and trying to defeat each other. Consequently, little attention is paid to delivering public goods for the benefit of the general public. Instead, the leaders of the respective factions prioritise dispensing patronage to known supporters or people they seek to pay off to join their respective camps.

The importance of patronage as a political tool in Sembabule is evident in the praise politicians receive for their generosity. They pay fees for schoolchildren, foot medical expenses for those who cannot afford to pay for themselves, locally and elsewhere, and make large contributions to funeral and wedding expenses. In some instances, the politicians have encouraged locals to form groups through which hand-outs can be organised, dispensed and shared out. Meanwhile, at both the local and national level, the NRM as a party has not acted to stop the factionalisation and the damage it has wreaked on service delivery.

Lyantonde, meanwhile, presents us with the other side of the coin of NRM politics, which creates ample space for those who are motivated to do good, as it does also for those whose motivations orient them towards using office for personal pursuits. There are no obvious political factions in the district. Instead, there is striking unity of purpose within the local political elite. Elected officials seek to build their legitimacy on delivering public goods, which is seen as possessing the potential to help reverse the feelings of marginalisation that the locals have long harboured. In this, they have enlisted the support of 'sons of the soil', technical personnel, CSOs and local communities, and sought and received assistance from the central government.

As demonstrated or affirmed by our local-level findings, problems in the health sector are also linked to factors that stretch beyond politics and spill over into the technical realm. Even within a framework of decentralised governance, it is essential that the central government retain adequate capacity for supervision, inspection and enforcement of standards. In Uganda, this capacity is deficient. In addition to higher-level health facilities being required to supervise and hold to account lower-level facilities operating under their watch, the Ministry of Health has the duty, also, to carry out routine supervision, as does the Office of the Prime Minister to oversee the ministry. Research over the last two decades (Golooba-Mutebi, 1999; Booth and Cammack, 2013) has pointed to weaknesses in supervision within the hierarchy of health facilities, with significant gaps in the oversight by district authorities over district hospitals and, consequently, further gaps in the supervision by district hospitals over lower-level facilities. Problems are compounded by the ministry's shallow stewardship of the sector, with the department responsible for standards setting and enforcement severely 
understaffed, ${ }^{46}$ and in turn weaknesses in higher-level accountability mechanisms through which the ministry itself should be held to account.

A key reason for the continued disruption of, and poor performance by, the health sector in Sembabule is its disconnection from the Ministry of Health, which neither supervises nor engages it on an on-going basis. Even decisions and resolutions arrived at during the ministry's Annual Health Assembly, when the Annual Health Sector Performance Reports are released in the presence of representatives of the government, NGOs, CSOs, districts, and donors, are not always followed through. ${ }^{47}$ The ministry has area supervision teams whose role is to visit local governments and provide technical advice where necessary. They, however, have not been performing that function for some time, and have not been to Sembabule since 2008. This failure is linked to the rapid increase in the number of districts, which has not been accompanied by a commensurate increase in the number of supervisors (MoH and MSPH, 2012).

Given the political situation in the district, however, it is doubtful that consistent oversight by the ministry would have had any effect on the sector. The experience of the Medicines and Health Services Delivery Monitoring Unit (MHSDMU) sheds ample light on this argument. The MHSDMU was established to troubleshoot and address problems in the health sector all over Uganda, as a result of much public dissatisfaction with public provision. Since it was set up, it has registered notable successes. For example, it has recovered money from individuals found guilty of misappropriation or diversion of resources; caused the arrest and prosecution of others in several districts; compelled district administrations to reallocate monies diverted from health services to other uses; and taken up direct supervision of such activities as health unit construction. ${ }^{48}$ However, it has so far failed to bring order to Sembabule, where at the heart of the problems in the health sector are the political machinations of two prominent personalities in the ruling party. Sources within MSHDMU intimated that the head, perhaps aware of the influence of the two personalities, had advised her staff to 'go slow' in trying to seek a solution. There are indications that, even in other districts, where influential personalities are involved in activities that are injurious to the sector, the president is consulted about what course of action to take. ${ }^{49}$ However, although he usually promises to take action, he does not (ibid).

Relatedly, despite a general increment in the financial resources allocated to the sector, the level of funding channelled into the health services for which local governments are responsible, is still low. Recurrent budgets under the government's primary healthcare (PHC) grant have not increased. If anything, the rapid rise in the number of administrative units has meant that there are fewer resources to go round. Moreover, less and less emphasis has been laid on financing primary prevention activities at district level. For the most part they are left to NGOs.

\footnotetext{
${ }^{46}$ Interview, Ministry of Health.

47 Interview with a key informant.

48 Interviews with MHSDMU personnel.

49 President Museveni is the single most dominant personality in the weakly institutionalised organisation in which his authority is unassailable.
} 
Overall, NGOs play a critical role in service delivery in the health sector. They have continued to fill the gaps left by inadequate state provision by delivering services directly to the public through their own facilities. Some finance public facilities, or partner with them or with local governments to deliver services that would otherwise not be available because of resource constraints. Thanks to a paradigm shift in international development from using NGOs to bypass the state to encouraging co-production of services, many collaborate with the state in pursuit of systems strengthening. Without regular support supervision from the ministry and district authorities, NGOs often co-deliver services with lower-level public facilities, often filling the supervision gaps. However, their supervisory role does not extend beyond joint activities with a given facility. And it is not comprehensive.

There are other problems as well. One concerns where NGOs choose to work. They tend to prefer locations with good amenities. Also, whereas their programmes add much value to the work of local authorities, many of them are without clear sustainability plans (GoloobaMutebi and Bukenya, 2014). For example, through a USAID grant, Save the Children recruited a number of health workers for health facilities in Lyantonde district. However, the district administration now worries about how they will be maintained when the project closes this year. Further, there are few NGOs in Uganda that possess the capacity to influence the national government. Despite their importance in policy implementation, NGOs specialising in service provision are usually not that influential in the policy-making arena. For the most part, local Ugandan NGOs lack the capacity and resources to do advocacy work, and also have limited understanding of the technical aspects of delivery and of the inner workings of government ministries. Therefore, with the government's own accountability mechanisms showing much weakness, and with NGOs not filling the gaps adequately, in theory it should be up to the citizens to assert their rights and make demands. This, however, happens only in rare cases.

All in all, while service delivery in Lyantonde and Sembabule testifies to the importance of political settlements as facilitators or blockers, it also highlights the importance of technical factors, the willingness and capacity of service users to hold providers and their supervisors to account, and of the influence of other actors who play direct and indirect roles in the shaping of ideas and actual delivery. 


\section{References}

Aliga, I. (2011). 'Sembabule CAO blames loss of funds on unqualified staff'. Monitor Publications, 2 November.

Booth, D. and Cammack, D. (2013). Governance for Development in Africa: Solving Collective Action Problems. London: Zed Books.

Burkey, I. (1991). 'People's power in theory and practice: The Resistance Council system in Uganda'. Unpublished paper, Yale University.

Buse, K. and Booth, D. (2008). 'Donors and the political dimensions of health sector reform: The cases of Tanzania and Uganda'. Good Governance, Aid Modalities and Poverty Reduction Working Paper 7. London: Overseas Development Institute (ODI).

Cammack, D., Golooba-Mutebi, F., Kanyangolo, F. and O'Neil, T. (2007). 'Neopatrimonial politics, decentralisation and local government: Uganda and Malawi in 2006'. Good Governance, Aid Modalities and Poverty Reduction Working Paper Series, Working Paper 2. London: The Advisory Board for Irish Aid.

Carbone, G. M. (2007). 'Political parties and party systems in Africa: Themes and research perspective'. World Political Science, 3(3): 2363-4782.

CDC (Centers for Disease Control and Prevention) (2014). Saving Mothers, Giving Life: Maternal Mortality. Phase 1 Monitoring and Evaluation Report. Atlanta, GA: Centers for Disease Control and Prevention, US Dept of Health and Human Services.

Croke, K. (2012). 'The political economy of child mortality decline in Tanzania and Uganda, 1995-2007'. Studies in Comparative International Development 47: 441-463.

DFID (Department for International Development) (2010). 'Building peaceful states and societies'. DFID practice paper. London: DFID.

Di John, J. and Putzel, J. (2009). 'Political settlements: Issues paper'. International Development Department, University of Birmingham.

Fassin, D. (1992). Pouvoir et Maladie en Afrique: Anthropologie Sociale dans la Banlieue de Dakar. Paris: Presse Universitaire de France.

Foley, E. E. (2010). Your Pocket is What Cures You: The Politics of Health in Senegal. New Brunswick, NJ and London: Rutgers University Press.

Golooba-Mutebi, F. and Bukenya, B. (2014). Institutional and Political Economy Analysis of the Health Sector in Uganda. Report for Department for International Development (DFID).

Golooba-Mutebi, F. (1999). Decentralisation, Democracy and Development Administration in Uganda 1986-1996: Limits to Popular Participation. PhD dissertation, London School of Economics and Political Science, University of London.

Golooba-Mutebi, F. (2005). 'When popular participation won't improve service provision: Primary health care in Uganda'. Development Policy Review, 23(2): 165-82.

Golooba-Mutebi, F. (2011a). 'Museveni the radical feminist finally faces the wrath of Ugandan women'. The East African, 26 June. 
Golooba-Mutebi, F. (2011b). 'Maternal deaths: Why Ugandans are victims of their own civic incompetence'. The East African, 3 July.

Golooba-Mutebi, F. (2012). 'I survived because of God's mercy: Will Ugandans be saying that in 2072?' The East African, 28 July.

Green, E. (2015). 'Decentralization and development in contemporary Uganda'. Regional \& Federal Studies, 25:5, 491-508.

Green, E. (2010). 'Patronage, district creation, and reform in Uganda'. Studies in Comparative International Development 45:83-103.

Hickey, S. (2003). 'The politics of staying poor in Uganda'. CPRC Working Paper 37. Chronic Poverty Research Centre.

Hossain, N. (2010). 'Rude accountability: Informal pressures on frontline bureaucrats in Bangladesh'. Development and Change, 41: 907-928.

Independent Team (2010). 'NRM vs NRM election violence'. The Independent 1 September. Available: https://www.independent.co.ug/nrm-vs-nrm-electionviolence/ (accessed 28 January 2019).

Jaffre, Y. and Olivier de Sardan, J.-P. (eds.) (2003). Une Médecine Inhospitalière: Les Difficiles Relations entre Soignants et Soignés dans Cinq Capitales d'Afrique de l'Ouest. Marseille: APAD; and Paris: Karthala.

Kaaya S. K. (2009). 'Museveni leaves Sembabule on fire'. The Observer, 24 December. Available online: http://observer.ug/news-headlines/6580museveni-leaves-sembabule-on-fire (accessed 6 December 2018).

Karugire, S. R., 1971. A History of the Kingdom of Nkore in Western Uganda to 1896. Oxford: Clarendon Press.

Kobusingye, O. (2010). The Correct Line? Uganda Under Museveni. Milton Keynes: Author House.

Leonard, D. (2000). Africa's Changing Markets for Health and Veterinary Services: The New Institutional Issues. New York: St. Martins Press.

Loewenson, R. and Apunyo, A. (2011). Civil Society Advocacy for Sexual and Reproductive Health, Uganda. World Health Organisation and HLSP.

Lyantonde District Local Government (2011). 'Approved five year district development plan (FY 2011/12 - 2015-2016)'. Lyantonde District Planning Unit.

Mambule, A. (2014). 'Sembabule where health centres are deathtraps'. The Observer, 18 July.

Medicines and Health Service Delivery Monitoring Unit (MHSDMU) (2014). Lyantonde District Health Status Report July 2014. Kampala: MHSDMU.

Ministry of Health (MoH) (2010). Health Sector Strategic Plan III, 2010/11-2014/15. Kampala: Ministry of Health.

Ministry of Health (MoH) (2013). Annual Health Sector Performance Report. Financial Year 2012/2013. Kampala: Ministry of Health.

Ministry of Health (MoH) (2014). Annual Health Sector Performance Report. Financial Year 2013/2014. Kampala: Ministry of Health.

Ministry of Health (2015). Human Resources for Health Commitments (2014/152018/19). Fast-tracking of the National Health Policy and HRH Strategic Plan to Achieve Universal Health Coverage. Kampala: Republic of Uganda. 
Ministry of Health, Health Systems 20/20 and Makerere University School of Public Health (2012). Uganda Health System Assessment 2011. Kampala: Ministry of Health.

Mugaju, J., 2000. 'A historical background to Uganda's no-party democracy'. In J. Mugaju and J. Oloka-Onyango (eds.), No-Party Democracy in Uganda: Myths and Realities. Kampala: Fountain Publishers.

Mutibwa, P. (1992). Uganda since Independence: A Story of Unfulfilled Hopes. London: Hurst and Company.

National Development Plan (2015). The Second National Development Plan(NDPII) 2015/16 - 2019/20. Kampala: National Planning Authority (NPA).

Oketcho, V., Ezati, I., Odaga, J., Foster, A. A., McMahan, J. and Muldavin, L.(2015). 'Uganda on track for keeping human resources for health commitments'. Chapel Hill, NC: Intra Health International.

Okwero, P., Tandon, A., Sparkes, S., Mclaughlin, J. and Hoogeveen, J. G. (2010). 'Fiscal space for health in Uganda'. World Bank working paper 186. Washington, DC: World Bank.

Rubongoya, J. B. (2007). Regime Hegemony in Museveni's Uganda: Pax Musevenica. New York: Palgrave Macmillan.

Sabiti, B and Ssebunya, A. K. (2012). "What works for the poor": Local governance systems and the delivery of maternal health, water and sanitation in two rural districts of Uganda'. Unpublished research paper, Overseas Development Institute, London.

Shaffir, W. B. and Stebbins, R. A. (eds.) (1991). Experiencing Fieldwork: An Inside View of Qualitative Research. Newbury Park, CA, London, and New Delhi: Sage Publications.

Ssali, M. J. (2010). 'The Sembabule cauldron'. Daily Monitor, 29 August. Available online: http://www.monitor.co.ug/Magazines/PeoplePower/-/689844/998672/l5udurp/-/index.html (accessed 6 December 2018).

Ssekweyama, E. (2012). 'Sembabule doctor abandons health centre for private job'. Uganda Radio Network. 17 August. Available online: http://ugandaradionetwork.com/story/sembabule-doctor-abandons-healthcentre-for-private-job\#ixzz3e4B5UHwB (accessed 6 December 2018).

Tidemand, P. (1995). 'Popular versus state provision of local justice: The resistance councils in Uganda'. In S. Semboja and O. Therkildsen (eds.), Service Delivery under Stress in East Africa. London: James Currey.

Tripp, A. M. (2010). Museveni's Uganda: Paradoxes of Power in a Hybrid Regime. Boulder, CO: Lynne Rienner Publishers.

Turshen, M. (1999). Privatizing Health Services in Africa. New Brunswick, NJ and London: Rutgers University Press.

Twaddle, M. (1993). Kakungulu and the Creation of Uganda, 1868-1928. London: James Currey.

Uganda Bureau of Statistics (UBOS) (2014). National Population and Housing Census Provisional Results. November 2014. Revised Edition. Kampala: Uganda Bureau of Statistics. 
Political settlements and the delivery of maternal health services in rural Uganda

Uganda Government/Ministry of Local Government (1993). Decentralisation: The Policy and Its Philosophy. Kampala: Ministry of Local Government/Decentralisation Secretariat. 


\section{Appendix 1: Map of Uganda showing the study districts}

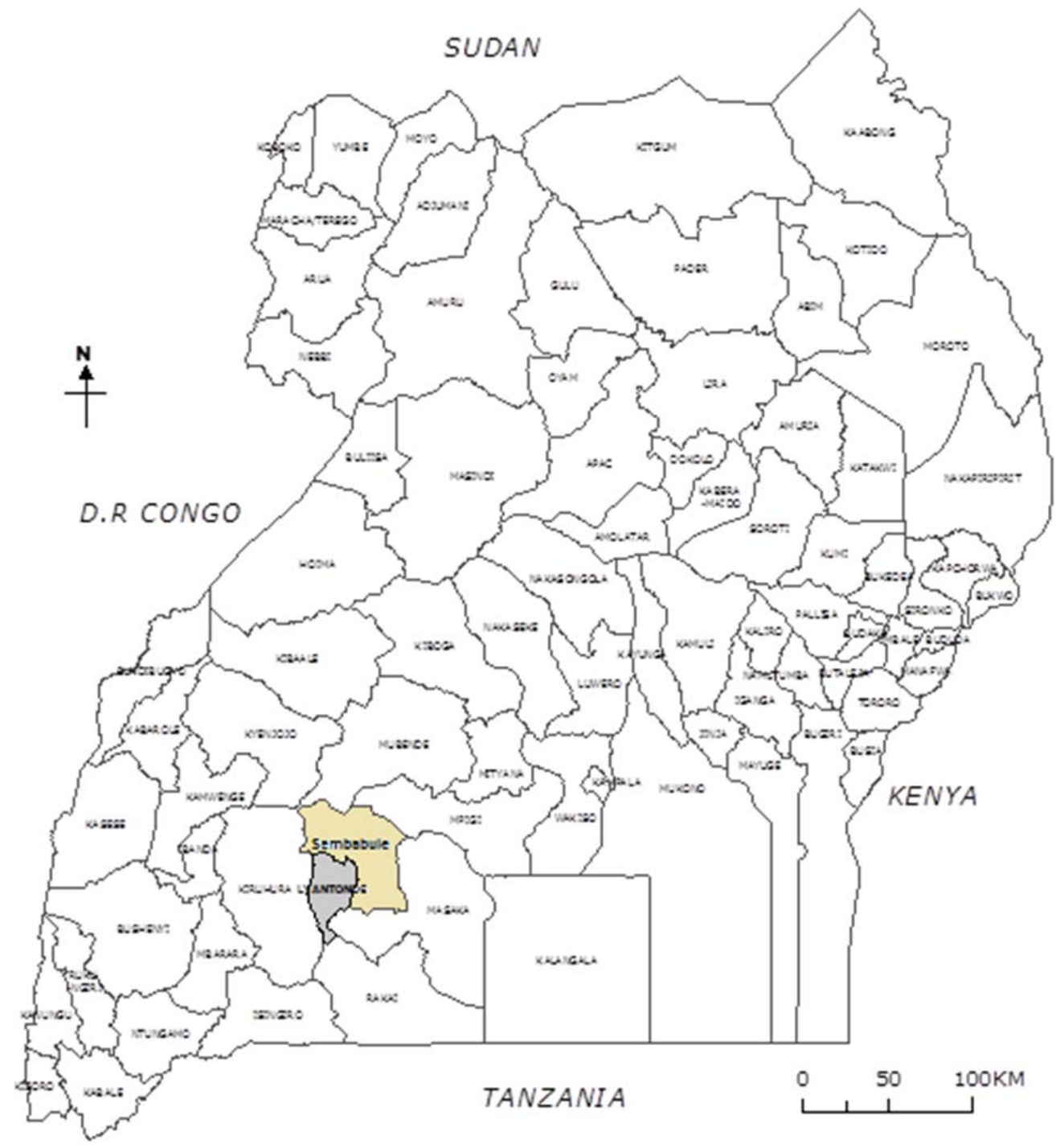

RWANDA 
Appendix 2: Maternal health indicators for Uganda

\begin{tabular}{|l|l|l|l|l|l|}
\hline Indicator & $\mathbf{2 0 0 0}$ & $\mathbf{2 0 0 5}$ & $\mathbf{2 0 1 0}$ & $\mathbf{2 0 1 2 / 1 3}$ & $\begin{array}{l}\text { Target } \\
\mathbf{2 0 1 5}\end{array}$ \\
\hline Deliveries in health facility & 24 & 29 & 33 & 41 & 90 \\
\hline Maternal mortality ratio & 505 & 435 & 435 & 438 & 131 \\
\hline $\begin{array}{l}\text { \% health centres without medicine stock } \\
\text { outs }\end{array}$ & $\mathrm{Na}$ & 27 & 41 & 53 & 70 \\
\hline $\begin{array}{l}\text { \% approved positions filled by qualified } \\
\text { health worker }\end{array}$ & 40 & 75 & 56 & 63 & 75 \\
\hline $\begin{array}{l}\text { Births attended by skilled health } \\
\text { personnel }\end{array}$ & 31 & 42 & 40 & 59 & 75 \\
\hline Government allocation to health & & & 8.3 & 7.9 & 15 \\
\hline Catastrophic payments & & & 43 & & 13 \\
\hline Absenteeism & & & 72 & 78 & 75 \\
\hline Villages with VHT & & & 21 & 53 & 80 \\
\hline \% health facilities with no stock out & & & 46 & $\mathrm{~N} / \mathrm{A}$ & 70 \\
\hline Client satisfaction & 47 & 32 & 48 & 34 & 60 \\
\hline 4 ANC attendances & & 24 & 36 & 50 \\
\hline $\begin{array}{l}\text { HC IVS that provide emergence } \\
\text { obstetrics services }\end{array}$ & & 24 & 30 & & 40 \\
\hline $\begin{array}{l}\text { Postnatal care (\% of women receiving a } \\
\text { postnatal check-up in the first two days } \\
\text { after birth) }\end{array}$ & & & $22.5 \%$ & $29 \%$ & \\
\hline HC IVs providing EmONC & & $23 \%$ & & 50 \\
\hline Contraceptive prevalence rate & & & & \\
\hline
\end{tabular}

Source: Authors' compilation. 
Appendix 3: Total budget allocations to the health sector (2000/012013/14)

\begin{tabular}{|l|l|l|l|l|l|}
\hline Financial year & GOU & Donor & Total & $\begin{array}{l}\text { Per capita } \\
\text { (US \$) }\end{array}$ & $\begin{array}{l}\text { Health as \% } \\
\text { of total GoU } \\
\text { budget }\end{array}$ \\
\hline $2000 / 01$ & 124.23 & 114.77 & 239 & 5.9 & 7.5 \\
\hline $2001 / 02$ & 169.79 & 144.07 & 313.86 & 7.5 & 8.9 \\
\hline $2002 / 03$ & 195.96 & 141.96 & 337.92 & 7.3 & 9.4 \\
\hline $2003 / 04$ & 207.8 & 175.27 & 383.07 & 7.7 & 9.6 \\
\hline $2004 / 05$ & 219.56 & 146.74 & 366.3 & 8 & 9.7 \\
\hline $2005 / 06$ & 229.86 & 268.38 & 498.24 & 14.8 & 8.9 \\
\hline $2006 / 07$ & 242.63 & 139.23 & 381.86 & 7.8 & 9.3 \\
\hline $2007 / 08$ & 277.36 & 141.12 & 418.48 & 8.4 & 9 \\
\hline $2008 / 09$ & 375.46 & 253 & 628.46 & 10.4 & 8.3 \\
\hline $2009 / 10$ & 435.8 & 301.8 & 737.6 & 11.1 & 9.6 \\
\hline $2010 / 11$ & 569.6 & 90.4 & 660.0 & 9.4 & 8.9 \\
\hline $2011 / 12$ & 593.02 & 206.10 & 799.11 & 10.29 & 8.3 \\
\hline $2012 / 13$ & 630.77 & 221.43 & 852.2 & 9 & 7.4 \\
\hline $2013 / 14$ & 710.82 & 416.67 & 1127.48 & 12 & 8.7 \\
\hline
\end{tabular}

Source: (based on Ministry of Health, 2013; Oketcho et al., 2015).

Note: GOU= Government of Uganda. 


\section{esid}

\section{The Effective States and Inclusive Development Research Centre}

The Effective States and Inclusive Development Research Centre (ESID) aims to improve the use of governance research evidence in decision-making. Our key focus is on the role of state effectiveness and elite commitment in achieving inclusive development and social justice.

ESID is a partnership of highly reputed research and policy institutes based in Africa, Asia, Europe and North America. The lead institution is the University of Manchester.

The other institutional partners are:

- $\quad$ BRAC Institute of Governance and Development, BRAC University, Dhaka

- $\quad$ Center for Democratic Development, Accra

- $\quad$ Center for International Development, Harvard University, Boston

- Department of Political and Administrative Studies, University of Malawi, Zomba

- $\quad$ Graduate School of Development, Policy \& Practice, Cape Town University

- Institute for Economic Growth, Delhi

In addition to its institutional partners, ESID has established a network of leading research collaborators and policy/uptake experts. 